\title{
Mesoscale Features Observed in the Taiwan Mei-Yu Season
}

\author{
By George Tai-Jen Chen \\ Department of Atmospheric Sciences, National Taiwan University, Taipei, Taiwan, ROC \\ (Manuscript received 14 May 1991, in revised form 25 August 1991)
}

\begin{abstract}
Mei-Yu (Baiu in Japan) is a weather and climate phenomenon in the area of Japan, Taiwan, and subtropical China where the seasonal rainfall distribution reaches a peak in late spring and early summer due to the repeated occurrence of the Mei-Yu front. From the satellite pictures, the Mei-Yu front is usually accompanied by a nearly continuous cloud band with organized mesoscale convective systems (MCSs). To the south of the Mei-Yu front, a low-level jet (LLJ) is often observed and is closely related to the formation of MCSs and heavy rainfall events. As the Mei-Yu front approaches Taiwan, the front and the accompanying MCSs and LLJ tend to be affected by the mesoscale topography of Taiwan, the Central Mountain Range (CMR). Besides, the land-sea contrast coupled with island topography produces the land-sea breeze, the mesolow, and the island circulations which are important in modulating the local precipitation.

In this paper, an overview of the current understanding of the structure and dynamics of the mesoscale features observed in the Taiwan Mei-Yu season is presented. Research results in the preTAMEX era as well as those derived from TAMEX program are discussed for the Mei-Yu front, the LLJ, the MCSs, the mesolow, the land-sea breeze, and the island circulations.
\end{abstract}

\section{Introduction}

Subtropical East Asia is one of the most active monsoon regions in the world. Over this area, the cold and dry northeast monsoon air originates from the northern Asian continent in winter and the warm and moist southwest monsoon air comes from the tropical oceans such as the western Pacific, the South China Sea and the Bay of Bengal in summer. A transition phase occurs between the northeast monsoon and southwest monsoon flow regimes in late spring and early summer. During this transition period, a front tends to form in the deformation wind field between a migratory high to the north and the subtropical Pacific high to the south (Chen, 1977b; 1983). It is called the Mei-Yu front in Taiwan and China and the Baiu front in Japan. Synoptically, the Mei-Yu front often moves southeastward slowly in the early stage of its lifetime and appears as a quasi-stationary front in late stage. Although the individual Mei-Yu front often moves slowly southeastward after its formation, the mean position of the front undergoes sequential northward shift between May and July depending upon the intensity and the position of the large-scale circulations in the subtropical latitudes (Chen, 1988; Tao and Chen, 1987). Figure 1 shows the annual mean frequency distribution of $850 \mathrm{hPa}$ front in the Mei-

(C)1991, Meteorological Society of Japan
Yu season of Taiwan (mid-May to mid-June) and of the Yangtze River valley (mid-June to mid-July) (Chen, 1988). In the Taiwan Mei-Yu season, the axis of maximum frequency, indicating the mean position of the Mei-Yu front, is oriented approximately in an east-west direction extending from southern Japan to southern China. The mean position shifts northward to Japan and central China in the Mei-Yu season of Yangtze River valley. The average lifetime is 8 days for both the Taiwan and Yangtze River Mei-Yu fronts.

The seasonal rainfall distribution in Taiwan reaches a maximum during the Mei-Yu season (Chen and Wu, 1978; Wang, 1970) primarily due to the repeated occurrence of the Mei-Yu front. Satellite pictures usually show a long stratiform cloud band along the Mei-Yu front with vigorous convection embedded within the band (Chen, 1978a). Although the Mei-Yu front can be several thousand kilometers long, the cross-front dimension is within the mesoscale range. Among the many mesoscale features observed near the front, the most important are the organized mesoscale convective systems (MCSs). These convective systems tend to move along the front from west to east. As they move across the Taiwan Strait, they are often affected by the steep orography of Taiwan and produce locally heavy rainfall of up to a few hundred millimeters per day (Chen and $\mathrm{Wu}, 1985$; Chen et al., 1986; Chen 

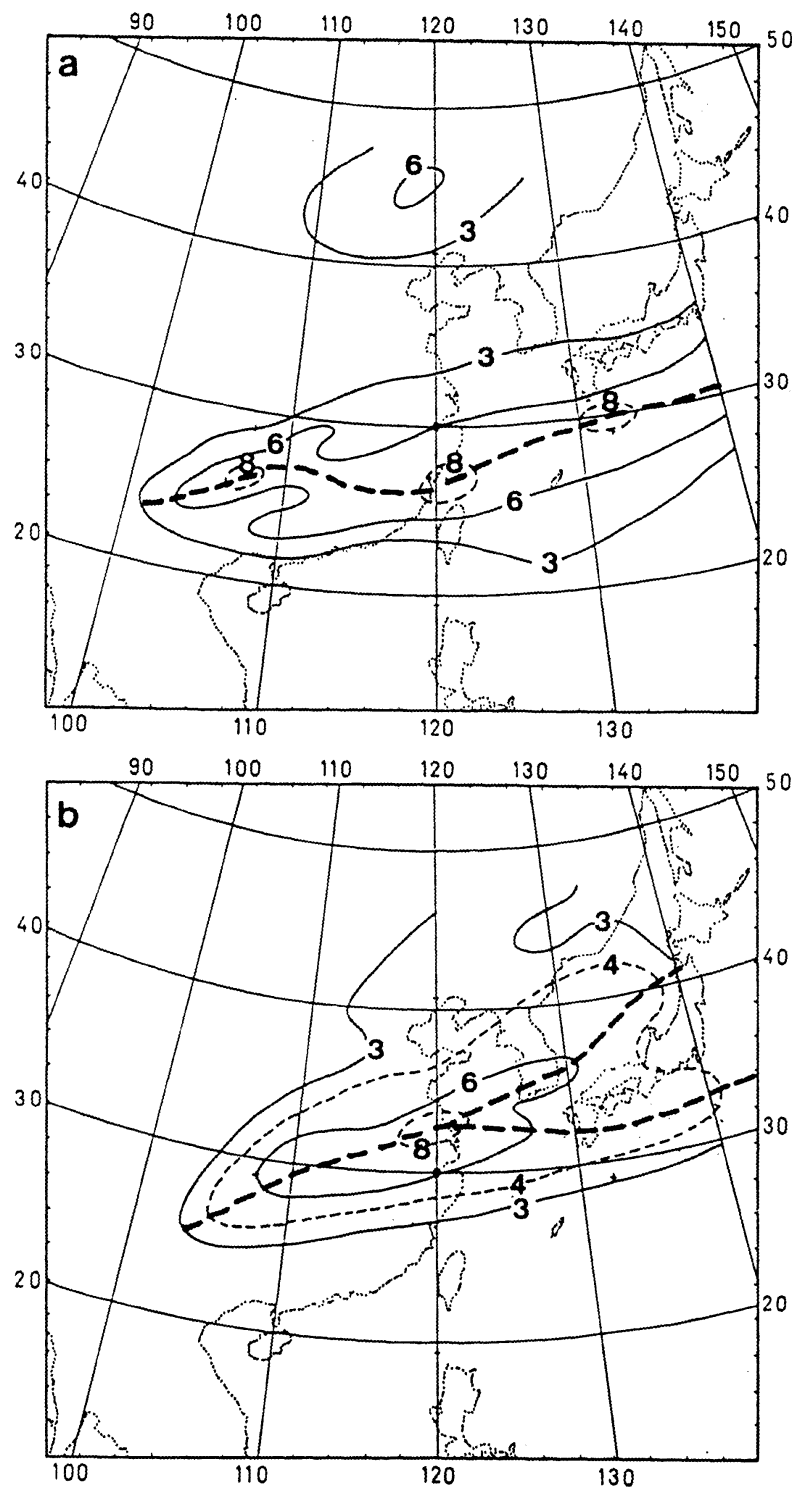

Fig. 1. Annual mean (1975-1986) frequency distribution of $850 \mathrm{hPa}$ front in (a) Taiwan Mei-Yu season (15 May-15 June) and (b) Yangtze River valley Mei-Yu season (16 June-15 July). Front frequency is counted at $12 \mathrm{~h}$ intervals and analyzed at $1^{\circ}$ lat $\times 1^{\circ}$ long grid intervals. Heavy dashed line indicates maximum axis (From Chen, 1988).

and Yang, 1988a). Figure 2 Shows the smoothed topography of Taiwan and the mean rainfall distribution during the 1972-77 Mei-Yu season (Chen, 1978b). The Central Mountain Range (CMR) runs through Taiwan in a north-south direction with an average terrain height of about $2000 \mathrm{~m}$ and a peak of $4000 \mathrm{~m}$. The topographic influence is clearly shown by the much higher values of rainfall on the windward slopes of the CMR than on the lee slopes under the prevailing southwesterlies in the lower

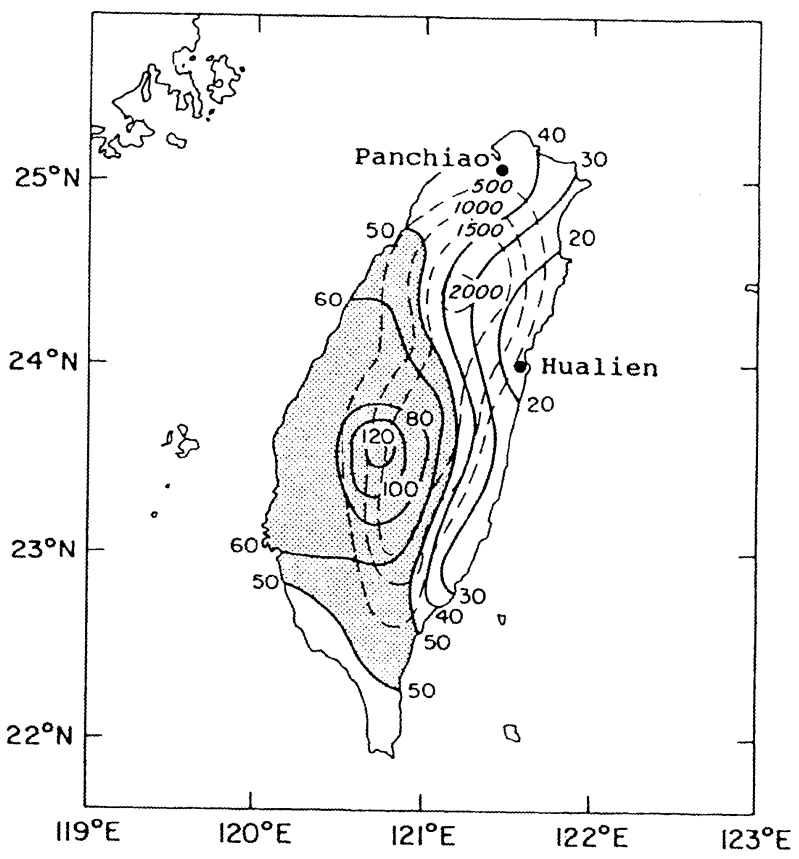

Fig. 2. The Mei-Yu rainfall(solid, $\mathrm{cm}$ ) in 15 May-18 June 1972-1977 and smoothed topography (dashed, $\mathrm{m}$ ). Shading indicates rainfall $\geq 50 \mathrm{~cm}$ (From Chen, 1978b).

troposphere. The CMR not only affects the MCSs, but also influences the Mei-Yu front and the prevailing flows. These topographic effects together with the strong local circulations generated by the landsea contrast and the mountain collectively determine the spatial and temporal distribution of Mei$\mathrm{Yu}$ rainfall in Taiwan.

The rainfall during the Mei-Yu season may be continuous or intermittent for several days to a few weeks and includes frequent rainshowers and thunderstorms (Hsu and Chi, 1974; Chen, 1983; 1990c). The property damage caused by heavy rainfall and the associated flash flooding in the Mei-Yu season becomes much more serious in recent years due to the rapid economy growth in Taiwan. Each of the heavy rainfall/flash flood events, such as the May 28 case of 1981, June 3 case and June 10 case of 1984 , caused U.S. \$400-600 millions in damage. With the awareness that the prediction of flash floods is greatly hampered by a lack of understanding of the mesoscale processes responsible for producing heavy rain, the National Science Council (NSC) of the Republic of China (ROC) in Taiwan established a mesoscale meteorological research program-the Taiwan Area Mesoscale Experiment (TAMEX).

The field phase of TAMEX extended from May 1 to June 29, 1987 covering thirteen Intensive Observing Periods (IOPs) and ten P-3 aircraft flight missions. The observational program of TAMEX consisted of five components: an upper-air network, a surface network, a radar network, an aircraft pro- 
gram, and a satellite program. The upper-air network was composed of conventional and special rawinsonde sites and pilot balloon stations. Nine of the 12 rawinsonde stations were land-based systems and three were located on ships, covering an area of $\sim 500 \mathrm{~km} \times 500 \mathrm{~km}$ centered over Taiwan. The surface network consisted of 75 surface stations, 126 raingauges, 21 wind towers, and 3 shipboard stations. The radar network consisted of five conventional radars and three C-band Doppler radars. From 11 May through 20 June 1987, the NOAA P-3 aircraft flew ten missions in support of eight TAMEX IOPs. The aircraft was based in Okinawa, Japan, though all flights were carried out in the TAMEX area. The meteorological satellites in operation during TAMEX were the GMS-3, NOAA-9, and NOAA-10. All standard data products available in real time as well as specially derived products (such as corrected SST and cloud wind vectors) were collected and archived at the ground-based satellite receiving station located at the Central Weather $\mathrm{Bu}-$ reau. During IOPs, routine observational systems increased their frequency of observations. "Fixed" special observing systems, such as Doppler radars, were operated in selected modes. Mobile observing systems, such as aircraft and ships, were deployed into areas of special interest. An overview paper of TAMEX field program was presented by Kuo and Chen (1990).

The goal of TAMEX is to improve, through better understanding, the forecasting of heavy rainfall events that lead to flash floods. The primary objective of the field phase was to collect the data necessary for the study of: 1) the mesoscale circulation associated with the Mei-Yu front, 2) the evolution of the mesoscale convective systems (MCSs) in the vicinity of the Mei-Yu front, and 3) the effects of topograghy on the Mei-Yu front and MCSs. The field program of TAMEX was an operational success and an excellent data set was available for studying various scientific problems relevant to heavy rainfall events. Mesoscale meteorological phenomena on which the TAMEX field observations were collected include: the Mei-Yu front, low-level jet (LLJ), pre-frontal squall lines, open-ocean MCSs, mountain convection, terrain-induced mesoscale circulation, frontal deformation due to topography, and land-sea breeze. Many papers have been presented in the TAMEX Workshop $(1989,1990)$ and published in various international journals. The research results of TAMEX have offered new insight into the structure and dynamics of these mesoscale phenomena.

The purpose of this paper is to present an overview of the current understanding of the structure and dynamics of the mesoscale features observed in the Taiwan Mei-Yu season. These include the Mei-Yu front, LLJ, MCSs, mesolow, land-sea

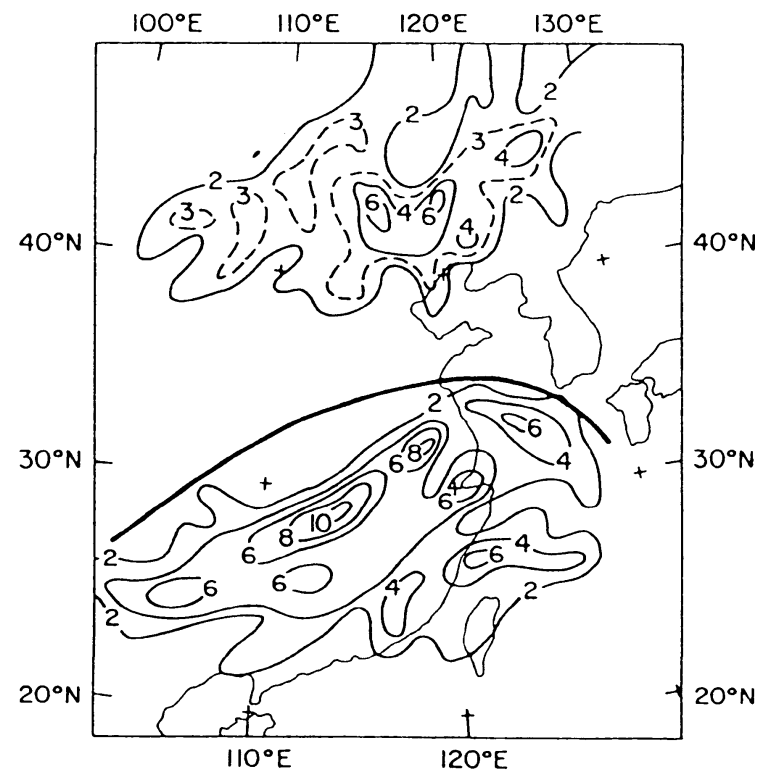

Fig. 3. Frequency of frontogenesis at $1^{\circ}$ lat $\times$ $1^{\circ}$ long grid intervals during the Taiwan Mei-Yu period of 15 May-15 June 196877 (1970 and 1975 excluded). The heavy solid line marks the boundary between the formation of the polar front and the MeiYu front (From Chen and Chi, 1980a).

breeze, and island circulations. Research results in the pre-TAMEX era as well as those derived from TAMEX program are reviewed and discussed for each mesoscale feature.

\section{The Mei-Yu front}

Chen and Chi (1980a) analyzed the frontogenesis frequency during the Taiwan Mei-Yu period of 15 May-15 June 1968-77. They found two distinct areas of frontogenesis: one in middle latitudes to the north of $40^{\circ} \mathrm{N}$ and the other in the subtropical latitudes to the south of $35^{\circ} \mathrm{N}$ (Fig. 3). The heavy solid line in Fig. 3 marks the boundary between the formation of the polar front and the Mei-Yu front. Among the Mei-Yu fronts analyzed in this period, 95 $\%$ influenced the weather near Taiwan during their lifetimes, and all the Mei-Yu fronts that reached Taiwan formed in the area of $20^{\circ}-35^{\circ} \mathrm{N}$ and $100^{\circ}-$ $130^{\circ} \mathrm{E}$. The lifetime of these fronts ranged from 3 days to 22 days with an average of 8 days. There are about $4-5$ frontal systems affecting Taiwan during the Mei-Yu season each year (Chen, 1988; Chen and Chi, 1978; 1980a). The stratiform and/or convective precipitation associated with the frontal system covers an area of $700 \mathrm{~km}$ wide across the front for both northern and southern Taiwan (Chen and Chi, 1978).

Chen and Chang (1980) studied the synoptic-scale structure and dynamics over different sections of the Mei-Yu front. The results indicated that the 

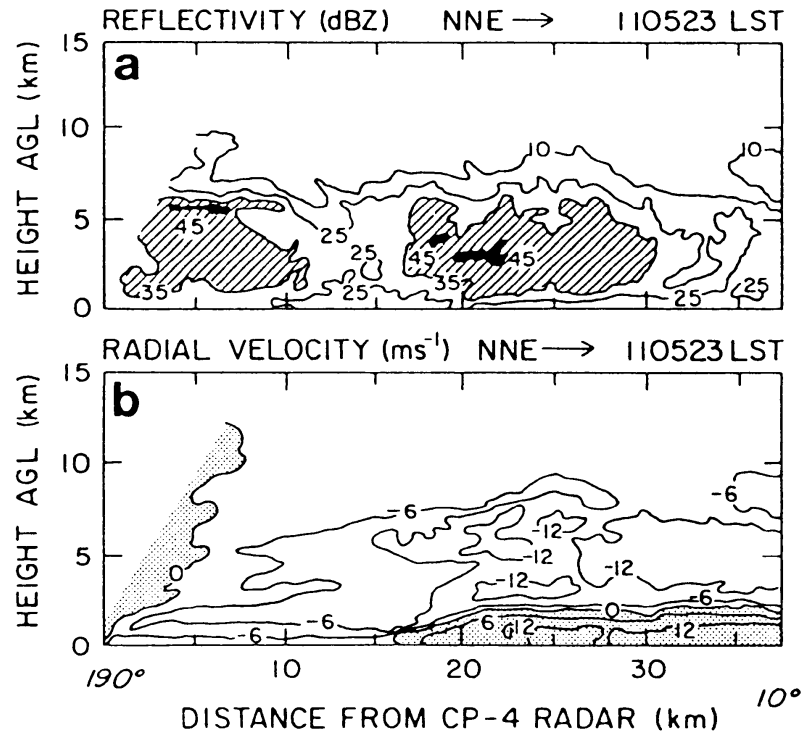

Fig. 4. Range-height indicator scans of (a) reflectivity and (b) radial velocity at 1108 LST 8 June 1987 at the NCAR CP4 radar site. The azimuth angle is $10^{\circ}$. The hatched region in (a) indicates reflectivity greater than $35 \mathrm{dBZ}$, and the darkened regions are greater than $45 \mathrm{dBZ}$. The shaded regions in (b) are for radial velocity (northeasterly flow) moving toward the radar (From Trier et al., 1990).

structure of the eastern (near Japan) and central (the East China Sea) sections resembles a typical midlatitude baroclinic front with strong vertical tilt toward an upper level cold core and a strong horizontal temperature gradient. Whereas the western (southern China) section resembles a semitropical disturbance with an equivalent barotropic warm core structure, a weak horizontal temperature gradient, and a rather strong horizontal wind shear in the lower troposphere. The vorticity budget showed that generation of cyclonic vorticity by horizontal convergence was counteracted by cumulus damping in the eastern section and by boundary layer friction in the mountainous western section.

Using TAMEX data, the mesoscale structure and new dynamical insight of the Mei-Yu front have been obtained. Case Studies showed that the Mei-Yu front may possess appreciable baroclinity with shallow cold air within the lowest $1 \mathrm{~km}$ (Chen and Hui, 1990; Chen et al., 1989; Trier et al., 1990). Figure 4 shows a vertical cross section of NCAR CP-4 radar reflectivity and radial velocity taken perpendicular to the orientation of a front on 8 June 1987 (Trier et al., 1990). The reflectivity is not very uniform with several convective cores $(Z \geq 45 \mathrm{dBZ})$ and the echo top is quite shallow extending to only $7-8 \mathrm{~km}$ AGL. The most interesting feature of this front is its shallowness, with a depth of $\sim 1 \mathrm{~km}$ at the leading edge, tilting to a depth of $1.5 \mathrm{~km}$ over a distance of 5 $\mathrm{km}$ and then becoming quasihorizontal. The highly baroclinic shallow nature of this front strongly suggests that the density-current-type structure at the leading edge is an inherent property of this front. The major features of this density-current-type front include a wind shift occurring on the scale of $1 \mathrm{~km}$, a convergence zone at the leading edge, and a steep slope with height of this wind shift followed by a more horizontally oriented frontal surface. It was suggested by Parsons et al. (1989) that the smaller and shallower updraft in TAMEX system as compared to a midlatitude system is due in part to the smaller magnitude of the maximum low-level convergence from a shallower and slower moving Mei-Yu front. As the fronts moved southward over Taiwan during the Mei-Yu season, air-sea interaction was suggested as a possible mechanism for the slowness (Chen and Chi, 1980a) and weakenning (Chen et al., 1989) of the fronts. An analysis of the Mei-Yu front presented by Trier et al. (1990) showed that the reduction of temperature contrast across front as the front moved southward was due to a warming and deepening of the postfrontal boundary layer and this warming could be explained by upward sensible heat flux.

The secondary circulation across the synopticscale Mei-Yu front was found to be thermally direct with warm air rising to the south and cold air sinking to the north of front (Chen and Chang, 1980). Using composite technique, Chen and Chi (1978) was able to observe two secondary circulation cells across the Mei-Yu front in northern Taiwan with one cell across the front and the other one to the south of the front. Convective activities were enhanced over the area of ascending part of the cell and were suppressed over the area of descending part. For the TAMEX cases, the thermally direct circulation of the Mei-Yu front was deduced from Doppler radar and P-3 aircraft observations (Chen and Hui, 1990; Jou et al., 1990; Trier et al., 1990). Figure 5 shows the thermally direct vortex circulation, derived from P-3 aircraft observations, at the leading edge of the front in the north-south cross section across a front to the east of Taiwan on 15 June 1987 (Chen and Hui, 1990). The slope at the leading edge of the cold air boundary was gentle, it rose to a depth of $800 \mathrm{~m}$ in a distance of $20 \mathrm{~km}$. At the top of the cold air behind the vortex circulation a wavelike pattern was observed with saturated air in the rising branches which was partially driven by the buoyancy force due to latent heat release.

Another interesting feature of the Mei-Yu front is its modification as influenced by the topography. Mesoscale analyses by Chen $(1978 b ; 1979 b)$ showed that the Mei-Yu front split into two branches, one to the east of Taiwan, and the other to the west, as the front approaches the CMR from the north. The 


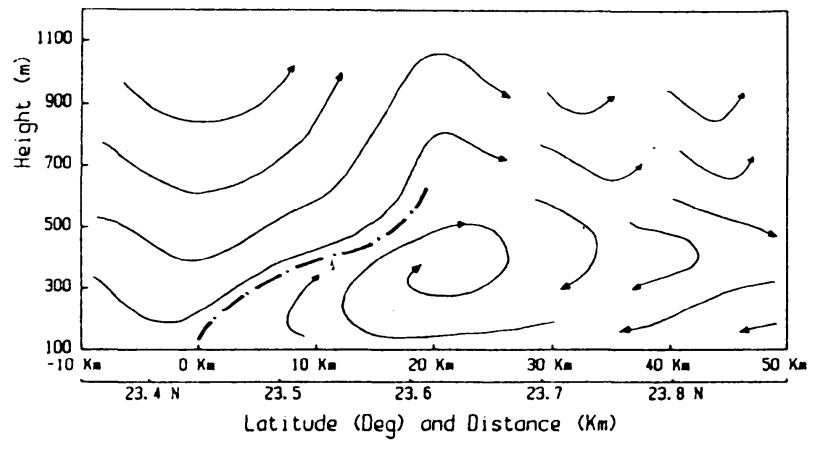

Fig. 5. The relative airflow in the north-south cross section across the front east of Taiwan during 1139-1407 UTC 15 June 1987. The estimated frontal speed, $6 \mathrm{~ms}^{-1}$, has been subtracted from the cross-front wind component. Dash-dotted line represents the leading edge of the cold air (From Chen and Hui, 1990).

eastern segment of the front often moves southward at a significantly faster speed than the western segment (Chen, 1978b; Wang, 1986). The frontal deformation with a different moving speed to the east and west of the CMR was also observed in TAMEX (Chen et al., 1989; Trier et al., 1990; Wang/S.T., 1989). Mannouji and Kurihara (1990) performed a numerical experiment for the frontal case on 24 June 1987 by using Japan Meteorological Agency (JMA) spectral model and found the essential role of the CMR on the distortion of the front with a faster moving speed on the east side only when mountain was included in the model. The strong ridging behind the leading edge of cold air along the east side of the CMR due to the blocking effect of the topography is quite similar to the case of cold air damming on the east slope of the Appalachian mountain chain in the eastern United States (Bell and Bosart, 1988; Forbes et al., 1987). The acceleration of highly ageostrophic flow of cold air parallel to the CMR in response to the building pressure gradient is perhaps responsible for the increase in propagation speed of the front along the east side of the mountain.

\section{Low level jet (LLJ)}

One of the very interesting features accompanying a Mei-Yu front is the existence of a LLJ to the south or southeast of the $850 / 700 \mathrm{hPa}$ trough (or shear line) (Chen, 1977a; 1978a; Matsumoto et al., 1971; Tao and Chen, 1987). Figure 6 presents an example of a LLJ in a vertical cross section along $120^{\circ} \mathrm{E}$ $(I=11)$ on 11 June 1975 (Chen, 1978a). In this case, LLJ is evident near $700 \mathrm{hPa}$ in the vicinity of Taiwan $(J=6)$ to the south of the Mei-Yu front. The $850 \mathrm{hPa}$ Mei-Yu front/shear line is clearly indicated by the intersection point of zero lines of $u$ and $v$
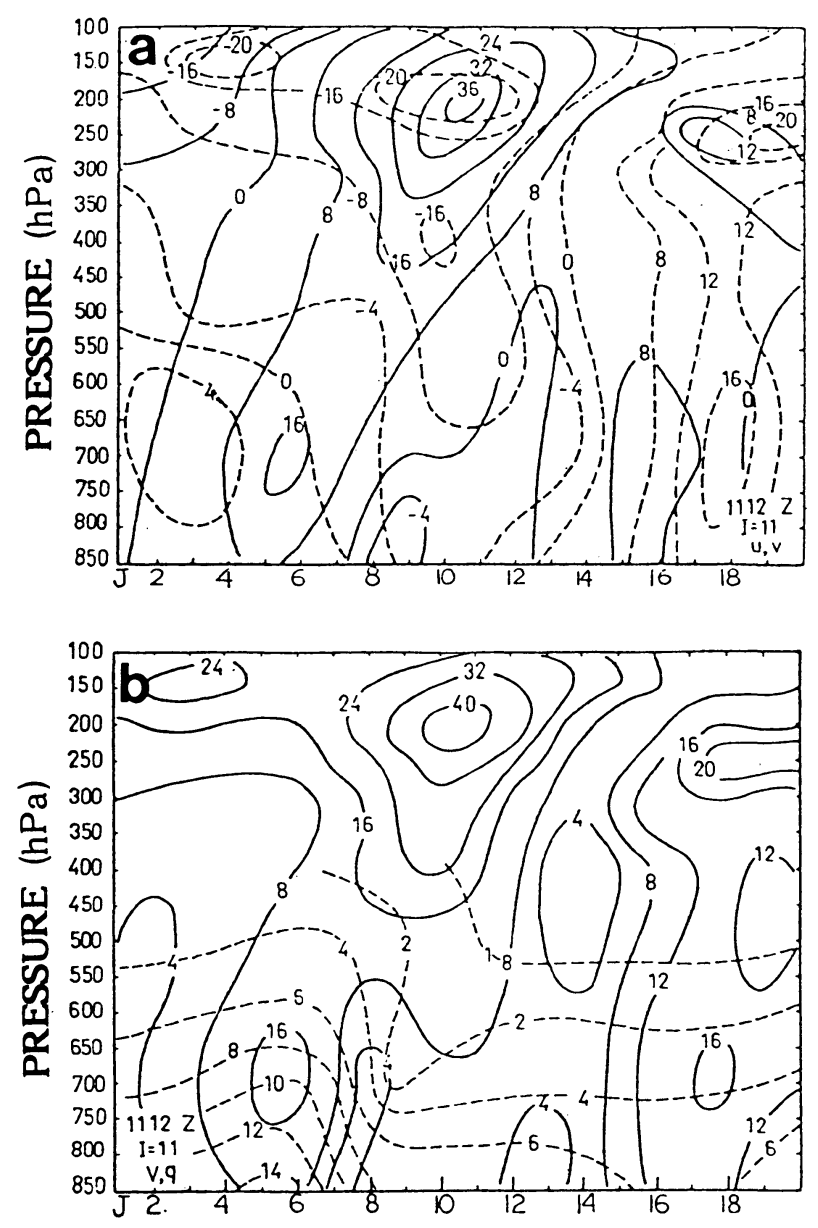

Fig. 6. Vertical cross sections of (a) east-west wind $(u$; solid) and north-south wind $(v$; dashed) components in $\mathrm{ms}^{-1}$, and (b) total wind speed (solid) in $\mathrm{ms}^{-1}$, and mixing ratio (dashed) in $\mathrm{g} / \mathrm{kg}$ along $I=11\left(120^{\circ} \mathrm{E}\right)$ at 1200 UTC 11 June 1975. Grid indices (J) in increasing order are from south to north, grid distance is $240 \mathrm{~km}$ (From Chen, 1978a).

(near $J=7$ ). It is clear that LLJ is a distinct feature of west-southwesterlies in contrast to the upper-level northwesterly jet. To the south of the Mei-Yu front, southerlies were generally confined in the lower troposphere below $500 \mathrm{hPa}$ with northerlies above. To the immediate north of the front, easterlies were usually limited in the lower troposphere below $700 \mathrm{hPa}$.

A close relationship between extremely heavy rainfall and a LLJ in the $850-700 \mathrm{hPa}$ layer during the Mei-Yu season has been found in many observational case studies over various geographic locations (Akiyama, 1973; Chen, 1979a; Chen, 1983; Chen and Chi, 1978; Matsumoto, 1972; Ninomiya and Akiyama, 1974; Tao and Chen, 1987; Tsay and Chain, 1987). The physical processes through which the existence of a LLJ leads to heavy rainfall have been proposed by Matsumoto (1972) who suggested 
that the upward branch of the secondary circulation associated with the LLJ is responsible for the heavy rainfall. Chen's (1977a) study, on the other hand, suggested that the LLJ is the main mechanism for creating potential instability to the warm side of a Mei-Yu front and for generating the convective heavy rainfall by the associated convergence downstream. Chen and Yu (1988) examined 35 heavy rainfall events over northern Taiwan in May and June during the years 1965-84. They found that there was an $84 \%$ chance that a LLJ with a maximum speed of at least $12.5 \mathrm{~ms}^{-1}$ would be present at $700 \mathrm{hPa} 12 \mathrm{~h}$ prior to the start of the heavy precipitation. Conversely, when a LLJ was present over northern Taiwan, there was a $91 \%$ likelihood that heavy precipitation was in progress or would begin within $24 \mathrm{~h}$. They also made a composite of vertical wind profiles for ten cases of heavy rainfall over northern Taiwan accompanied by a LLJ with an axis located within $1^{\circ}$ latitude from Taipei at each of the three time periods: 12 hours before heavy rainfall, at time of heavy rainfall, and 12 hours after rainfall. Figure 7 shows the results. It seems clear from the composite profiles that vertical shear above and below LLJ level as well as the LLJ intensity decreased at and after the time of the start of extremely heavy rainfall.

Ageostrophic characteristics of the LLJ over Japan area (Matsumoto et al., 1971) led to a hypothesis of downward momentum transport in the formation of a LLJ (Akiyama, 1973; Matsumoto and Ninomiya, 1969). Over the Taiwan area, on the other hand, a LLJ was usually observed prior to the major convections and decreased its intensity after the heavy rainfall (Chen and Chi, 1978; Chen and $\mathrm{Yu}, 1988)$. Also, the area of MCS formation was usually determined by the location and intensity of a low level jet (Chen, 1977a; Chen and Pu, 1985; Chiou and Liao, 1984). Therefore, it seems reasonable that at least some of the LLJs over Taiwan area were the cause rather than the effect of the convection. Observational study of Chen and $\mathrm{Yu}$ (1988) showed that a LLJ may form to the south of the heavy rainfall area and suggested that the secondary circulation associated with the Mei-Yu front presumably driven by convective latent heating is a possible formation mechanism for a LLJ. Although differences exist between the Taiwan and Japan LLJs and the reasonable explanation is not available at the present time, the formation and maintenance mechanism of the LLJs over different geographic areas is in fact a very interesting topic and deserves further discussion.

The formation and maintenance of a LLJ to the south of an area of extremely heavy rainfall (or MCS) has also been documented both in theoretical study (Chen, 1982) and numerical experiments (Chou et al., 1990; Ninomiya, 1980; Ninomiya and

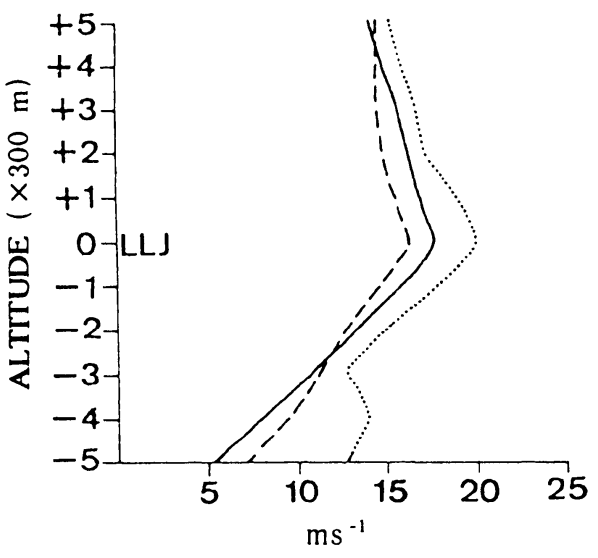

Fig. 7. Composite vertical wind profiles for ten cases of heavy rainfall over northern Taiwan accompanied by a LLJ with axis located within $1^{\circ}$ latitude from Taipei at each of the three time periods: 12 hours before heavy rainfall (dotted), at time of heavy rainfall (solid), and 12 hours after heavy rainfall (dashed). Wind speeds were composited with respect to the level of each LLJ. Abscissa is wind speed in $\mathrm{ms}^{-1}$, and ordinate is altitude at $300 \mathrm{~m}$ intervals above $(+)$ and below (-) the LLJ level (0) (From Chen and Yu, 1988).

Tatsumi, 1980). Results of Chen's study (1982) suggested that the existence of an unstable inertiagravity wave in the ascending motion region caused a thermally direct circulation beneath the upperlevel jet. A local temperature increase caused by condensation warming in the area of ascending motion accelerated the thermally direct circulation to the north and induced a reversed circulation to the south through the geostrophic adjustment process. It was concluded that the LLJ forms through the Coriolis acceleration of northward flow in the lower branch of this reversed circulation. Composite results of Tsay and Kau (1989) showed a strong vertical coupling between the upper-level jet and the LLJ. A LLJ tended to form to the south of the entrance region of an upper-level jet possibly through this process. This mechanism was further substantiated by a numerical study of Chou et al., (1990) who simulated the formation of a LLJ to the south of the area of strong convection in a two-dimensional frontogenesis model. In that study, the importance of cumulus convection and especially a slantwise structure in developing the reversed circulation and the LLJ was suggested. In addition, Ninomiya (1980) and Ninomiya and Tatsumi (1980) simulated the formation of a LLJ to the south of a convective heavy rainfall area in their primitive equation model with a convective adjustment process. They attributed the formation of LLJs to the increase of pressure gradient caused by convective warming to 
the north. Observational case studies (Lin, 1988; Lin and Chiou, 1985; Lin and Tsai, 1989; $\mathrm{Pu}$ and Chen, 1988) showed that a LLJ tends to form or to intensify to the south of an MCS in southern China. Thus, results of observational, theoretical, and numerical studies all suggested that a LLJ can form to the south of the convective heavy rainfall area presumably through the Coriolis acceleration of the lower branch of an induced secondary circulation. Over southern China, geostrophic forcing and lee cyclogenesis processes have also been suggested as possible mechanisms for the formation of LLJs in spring and Mei-Yu seasons (Chen and $\mathrm{Pu}, 1985 ; \mathrm{Pu}$ and Chen, 1988).

Over the Midwest of the United States, different mechanisms have been proposed to explain the formation of a LLJ. Observational study of Newton (1956) showed that a LLJ can form as a result of pressure gradient response to leeside cyclogenesis to the east of the Rockies. On the other hand, Wexler (1961) proposed that the formation of a LLJ is due to the combined effects of mountain friction and conservation of potential vorticity for the southerly flows over the western portion of the North Atlantic subtropical high. Blackadar (1957) explained the nocturnal formation characteristics of the LLJ as a result of inertial oscillation due to the boundarylayer mixing processes. On the other hand, Lettau (1967) explained that these nocturnal formation characteristics are due to the boundary-layer thermal wind variations caused by the diurnal radiation cycle over sloped terrain. Results of a numerical and observational study by Uccellini and Johnson (1979) showed that the LLJ can form due to the increace of lower-tropospheric isallobaric winds through the forcing process of upper-tropospheric jet streaks. No evidences indicate that the above mentioned mechanisms can be applied to the formation of LLJ in the Taiwan area as to the author's knowledge. Are those processes which contributed to the development of LLJs in Great Plains of the United States also important for the formation of LLJs in subtropical China and Japan during the Mei-Yu (or Baiu) season? This is an intriguing but relatively unexplored question. Apparently, more studies are needed to understand the mechanisms responsible for the formation of LLJs in the Mei-Yu season over different geographical areas.

One of the scientific objectives of TAMEX is to examine the structure of the LLJ and its relationship to MCSs. Several IOPs in TAMEX provided detail data for this purpose (Kuo and Chen, 1990). Similar to the previous studies, most of the LLJs observed in TAMEX area had their origin in the upstream region of southern China. As the LLJ moved toward Taiwan area, it appeared to be affected by the topography of Taiwan and intensified locally to the northwest of Taiwan. Analyses of

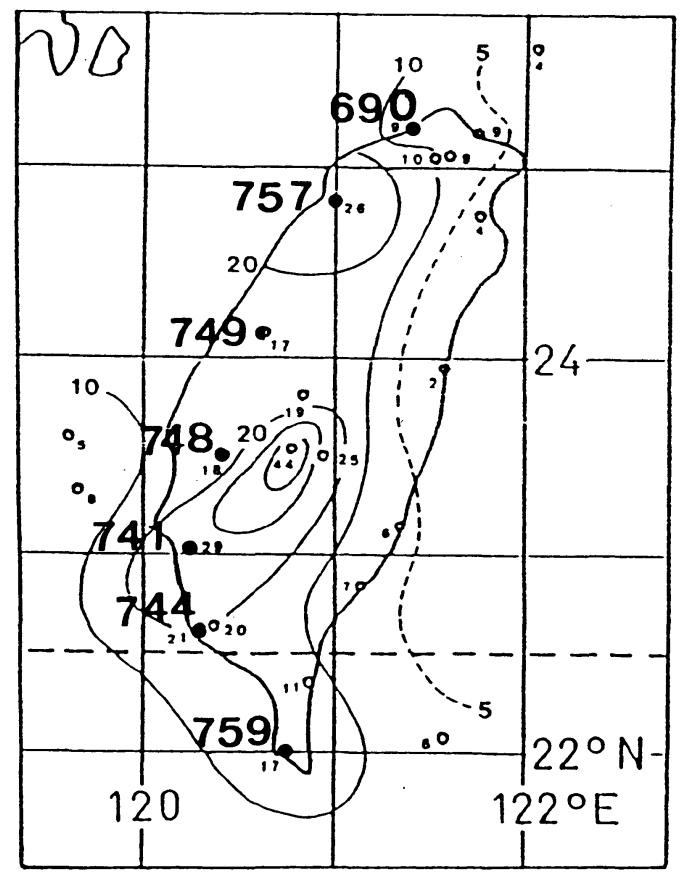

Fig. 8. Frequency distribution of heavy rainfall event $\left(\geq 100 \mathrm{mmd}^{-1}\right.$, ) in Taiwan MeiYu season of May-June 1975-1984. Solid circles show the station numbers: 690 (Tanshui), 757 (Hsinchu), 749 (Taichung), 748 (Chiayi), 741 (Tainan), 744 (Kaohsiung), 759 (Hengchun) (From Chen and Yang, 1988a).

TAMEX cases showed that the prevailing low-level southwesterly flows tended to be deflected upstream of the CMR due to the blocking effect of the mountain and the LLJ appeared to form to the northwest of Taiwan and to the southern tip of Taiwan (Shu, 1991). These observed features of flow deflection and the formation of a LLJ locally to the northwest of Taiwan were well captured in the model simulations by Huang and Raman (1990) and Mannouji and Kurihara (1990). The existence of the LLJ was found to be essential for maintaining the pre-frontal squall line by providing the strong vertical shear in the lower troposphere (Chen and Chou, 1989; Jou et al., 1990; Wang et al., 1990). The horizontal vorticity existed in the vertical shear tended to balance the horizontal vorticity produced by buoyancy gradients near the leading edge of the cold pool in those TAMEX squall line cases. This approximate balance was referred to as an optimal state for MCS development by Rotunno et al. (1988).

\section{Mesoscale convective systems (MCSs)}

Figure 8 shows the spatial distribution of heavy rainfall events in the Mei-Yu season of May and June (Chen and Yang, 1988a). The pattern reflects the influences of the CMR and local topography. The frequency was much higher on the windward 
side than on the leeside of the mountain. A primary maximum was observed in southwestern Taiwan over the maximum terrain slope (Fig. 2) and a secondary maximum was over the northwestern coastal area where the mesolow formation was a maximum (Chen, 1978b). Chen (1985) analyzed the heavy rainfall events over northern Taiwan in the Mei-Yu period of 1965-1984 and found an average of about 2 events per year. Twenty-seven of 37 heavy rainfall events in this 10 -year period occurred at night. This suggests the importance of diurnal modulation of precipitation due to local circulations. The maximum hourly rainfall at all stations in each event suggested that the topography was related to the spatial distribution of heavy rainfall. The heavy rainfall was also closely related to the Mei-Yu front in addition to the LLJ discussed in the previous chapter. Chen and Chi (1978) observed that the heavy rainfall usually occurred across the front in the area from $100 \mathrm{~km}$ ahead of the front to $200 \mathrm{~km}$ behind the front over northern Taiwan. On the other hand, it generally occurred over the area $200-300 \mathrm{~km}$ ahead of the front over southern Taiwan.

Case study of heavy rainfall event has become one of the most attractive topics in Taiwan since the time of occurrence of the disastrous event of May 28, 1981 over northwestern Taiwan (e.g. Chen, 1986; Chen, Chiou and Wang, 1986; Chi and Chen, 1988; Chiou and Liu, 1985; Liu, 1982). The main purpose of those case studies is to better understand the environmental conditions and to identify the mesoscale triggering mechanisms. In addition to those case studies, results of synoptic climatological studies of heavy rainfall also appeared to be very valuable in better understanding the necessary conditions of the heavy rainfall (Chen, 1985; 1990c; Chu et al., 1983; Liu, 1981).

The heavy rainfall producer is the MCSs. There are different sizes of MCSs embedded in the Mei-Yu frontal cloud band. Chen et al. (1986) studied the climatology of the MCSs over western Pacific and southern China in the Mei-Yu season of 1981-1983 using GMS satellite cloud pictures. Results showed that the duration of the Mei-Yu MCSs is similar to that observed over North America in warm season. The mean durations of the meso- $\alpha$ and meso- $\beta$ MCS are $14.6 \mathrm{~h}$ and $14.1 \mathrm{~h}$, respectively. These are somewhat shorter than that obtained by Maddox (1980) of 16.5 h over the U.S.. It was also found that the duration of MCS is positively correlated with its horizontal scale which increases in warmer seasons. The MCS in subtropical China tends to move southeastward over land and then recurves eastward or northeastward offshore. The afternoon maximum of the MCS formation over land was apparently due to solar heating. The early morning maximum of the MCS intensification was suggested to be due to the differential radiation effect between the cloudy and cloud-free area.

Since heavy rainfall in the Mei-Yu season is produced by the MCS embedded in the frontal cloud band, the environmental conditions are similar for the heavy rainfall and for the MCS (Chen, 1977b; Chi and Chen, 1988; 1989b; 1989c; Chiou and Chen, 1989; Chu and Chen, 1988; Lin, 1988; Lin and Lin, 1989). These synoptic case studies for the MCSs over Taiwan and southern China suggested that there are at least six conditions favorable for the development of MCS. They are (1) warm advection in the lower troposphere, (2) low-level convergence over the low pressure and/or the front, (3) low-level jet, (4) short wave trough in the lower to middle troposphere, (5) the middle and upper troposphere diffluent flow and/or speed divergence, and (6) potential instability in the lower and middle troposphere.

Tsay and Chen (1980) pointed out that the largescale upward motion to the south of the Mei-Yu front was generated mainly by vertical differential of the horizontal vorticity advection, Laplacian of the temperature advection, low-level frictional effect, and convective latent heating. However, the relative importance of these forcing terms is different over Japan, Taiwan and southern China. The areas of this large-scale upward motion and the horizontal moisture flux convergence were the areas favorable for the development of MCSs (Chen/C.S., 1990; Chen, 1979a; Chen and Chang, 1980; Chen and Tsay, 1978; Chi and Chen, 1989c; Kuo and Anthes, 1982; Lee, 1990; Wu and Chen, 1988). Figure 9 shows the composite structure of environmental conditions for the 12 cases of meso- $\alpha$ scale MCS (i.e., MCC) selected in May-June 1981-1986 in their formation and mature stages. The overall structure is quite similar to that for the midlatitude MCC in the North America as obtained by Maddox (1983). The MCC formed and intensified in the warm sector to the south of the Mei-Yu front/shear line. The strong warm advection and speed convergence (i.e., convergence due to the downstream speed decrease) in the lower-tropospheric southwesterlies, possible lifting mechanisms in the formation and intensification stages, prevailed over the area of MCC. The MCC tended to form and to intensify on the cyclonic side of the LLJ exit region. Anticyclonic circulation and diffluent flow in the upper troposphere provided conditions favorable for the intensification of MCC.

Observational studies suggested that some mesoscale circulation systems are apparently responsible for the formation of the MCSs over Taiwan and southern China. These include the frontal secondary circulation, low-level jet, quasi-stationary mesolow, terrain induced flow, outflow boundary and local circulations (Chen/C.K., 1979; Chen/C.S., 1989; Chen, 1977a; 1978b; 1990b; Chen and Chi, 1978; 1980b; Chen and Yu, 1988; 1990; Chi and 

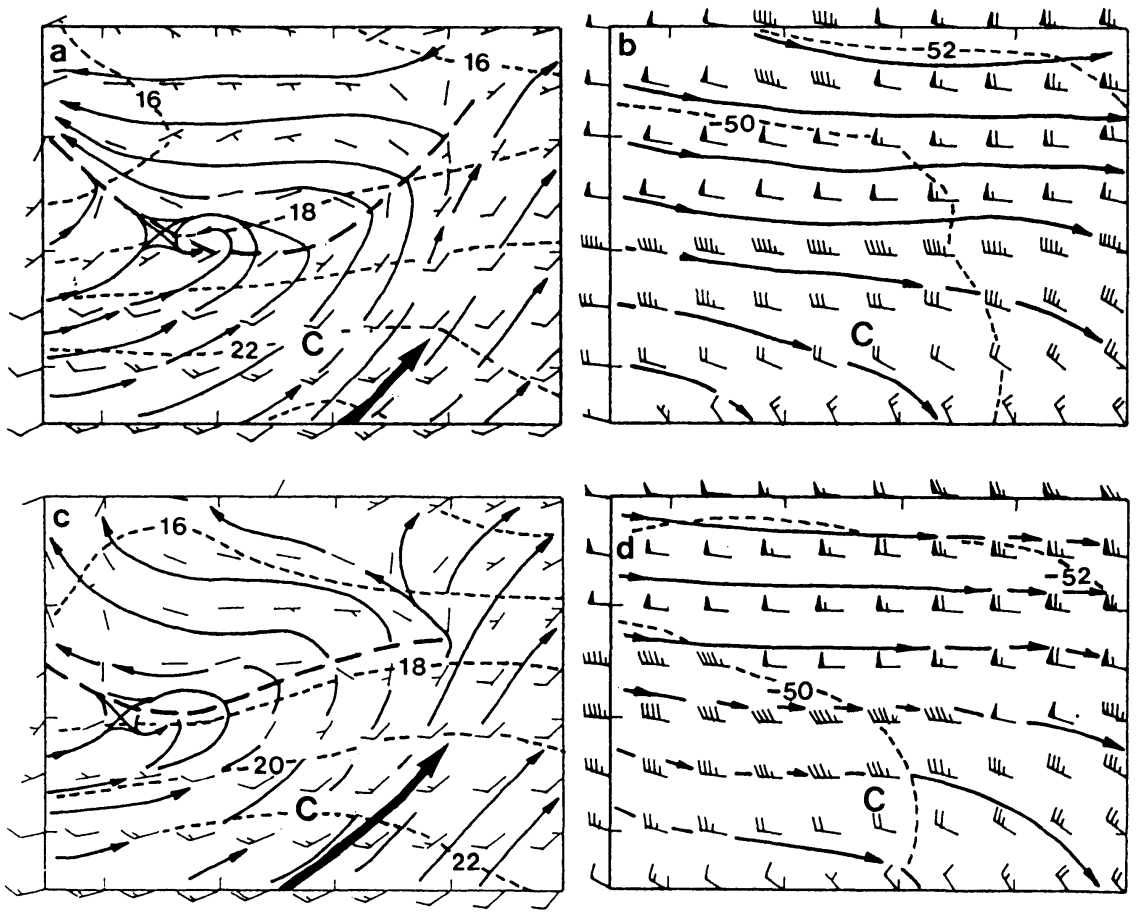

Fig. 9. Composite structure for 12 cases of meso- $\alpha$ scale MCS selected in May-June 1981-1986 in the (a) formation stage at $850 \mathrm{hPa}$, (b) formation stage at $200 \mathrm{hPa}$, (c) mature stage at $850 \mathrm{hPa}$ and (d) mature stage at $200 \mathrm{hPa}$. Wind plots are conventional at $2.5^{\circ}$ lat $\times 2.5^{\circ}$ long grids. Streamlines (solid) and temperature (dashed, ${ }^{\circ} \mathrm{C}$ ) are analyzed. Heavy arrow indicates LLJ position, heavy dashed line shows the Mei-Yu shear line, and C indicates the MCS position (From Wu and Chen, 1988).

Chen, 1989b; Lin and Lin, 1988; Trier et al., 1990). The mesoscale circulation systems appear to be important mechanisms for creating greater instability over a smaller area and providing stronger lifting necessary for the mesoscale convections. This is one of the major reasons for this paper to discuss these mesoscale features in the Taiwan Mei-Yu season.

Climatological aspects of convective rainfall in Taiwan were strongly modulated by the local circulations in Mei-Yu season (Chen and Yang, 1988b; Bresch and Johnson, 1990). Figure 10a shows the diurnal frequency of the convective rainfall events $\left(\geq 15 \mathrm{mmh}^{-1}\right)$ on the western side of the CMR from north to south (see Fig. 8 for station location) in 1975-1984. The convective rainfall occurred mainly in the daytime hours (0900-2000 LST), indicating the importance of solar heating effect. Besides, the occurrence time of maximum frequency appeared to correlate well with the inland distance of the station. The coastal stations had a peak frequency in the morning and the inland stations in the afternoon. This seems to indicate the importance of see breeze in modulating the convective rainfall. An example of diurnal variations of the winds and convective rainfalls is presented in Figs. 10b and 10c. It is clear that the land-sea breeze circulations prevailed and the peak frequency of convective rainfall occurred when the sea breeze started. It is to be noted that majority of the heavy rainfall events over northern
Taiwan occurred at night, whereas the convective rainfall occurred mainly in the daytime hours on the western side of the CMR. This tends to suggest that the characteristics of the MCSs in heavy rainfall are defferent from the MCSs produced by the sea breeze and solar heating effect.

In TAMEX, Doppler radar and P-3 aircraft observations provided a great opportunity for studying the general characteristics and internal structure of the MCSs. Jorgensen and LeMone (1989) studied the vertical velocity characteristics of oceanic convection in the vicinity of Taiwan. They observed that the drafts and cores in TAMEX are comparable in size and strength with those measured in GATE and hurricanes but much weaker than those measured in continental thunderstorms. They also found that the oceanic convection in TAMEX is dominated by warm rain coalescence processes, similar to that in GATE and hurricanes, and that a large fractional rainout occurs below the freezing level. The internal structure and dynamics of MCSs in different TAMEX cases were studied extensively by various investigators (e.g. Jou et al., 1990; Lin et al., 1989; Lin et al., 1990; Wang, 1988; 1989; Wang et al., 1990). Case study of a north-south oriented pre-frontal squall line on 17 May 1987 (IOP 2) by Wang et al. (1990) showed that many structural features are similar to those for a fast-moving tropical squall line. Figure 11 shows an east-west vertical 

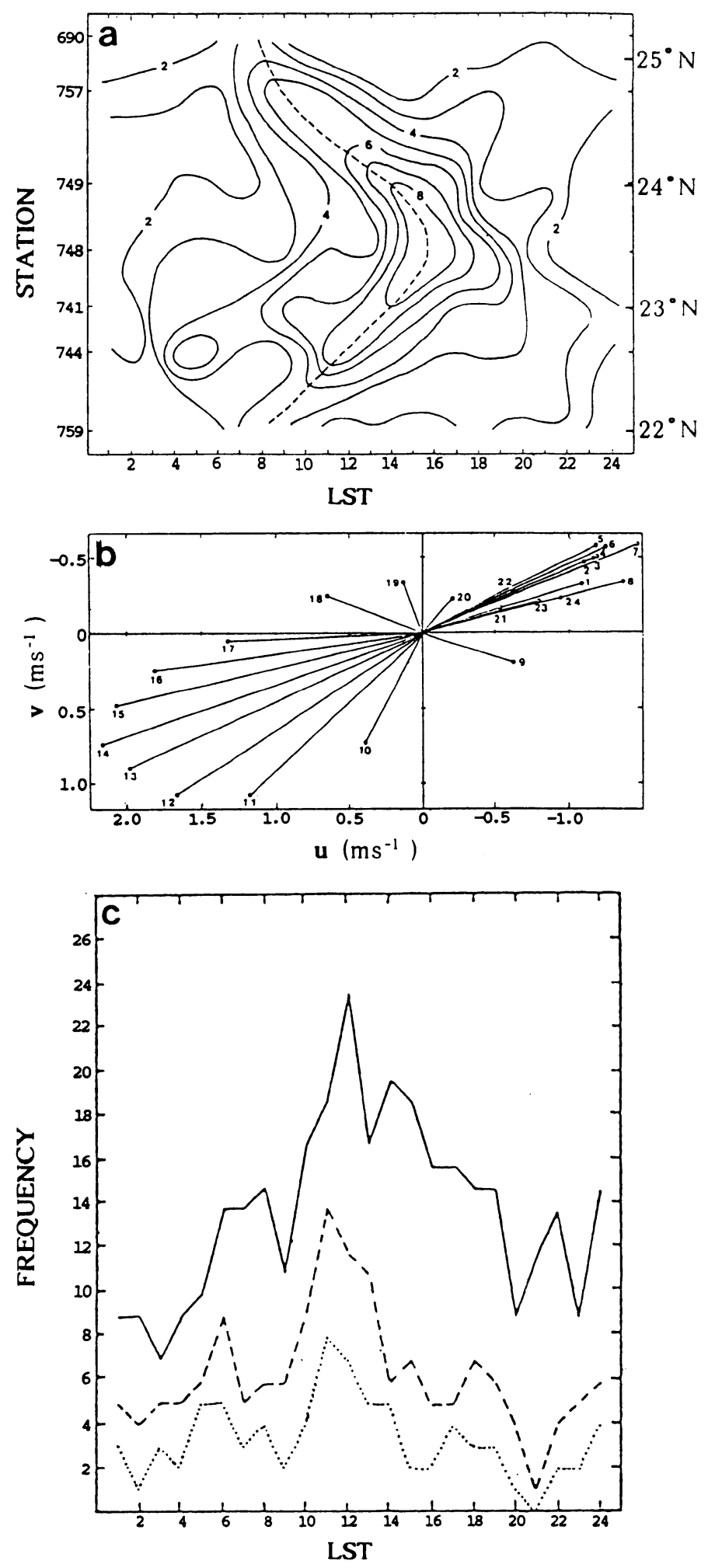

Fig. 10. (a) Diurnal frequency distribution of convective rainfall event of $\geq 15 \mathrm{mmh}^{-1}$, on the west side of the Central Mountain Range from south to north (ordinate) in May-June 1975-1984. Dashed lines indicate maximmber frequency and abscissa is the LST. Station number in ordinate is shown in Fig. 8. (b) Diurnal wind variations at Kaohsiung in the same period. $u$ and $v\left(\mathrm{~ms}^{-1}\right)$ are in abscissa and ordinate, respectively. Number in the diagram is LST. (c) Diurnal frequency distribution of convective rainfalls (solid $\geq 5 \mathrm{mmh}^{-1}$, dashed $\geq 10 \mathrm{mmh}^{-1}$, dotted $\geq 15 \mathrm{mmh}^{-1}$ ) at Kaohsiung in the same period. Abscissa is LST and ordinate is the frequency (From Chen and Yang, 1988b). 

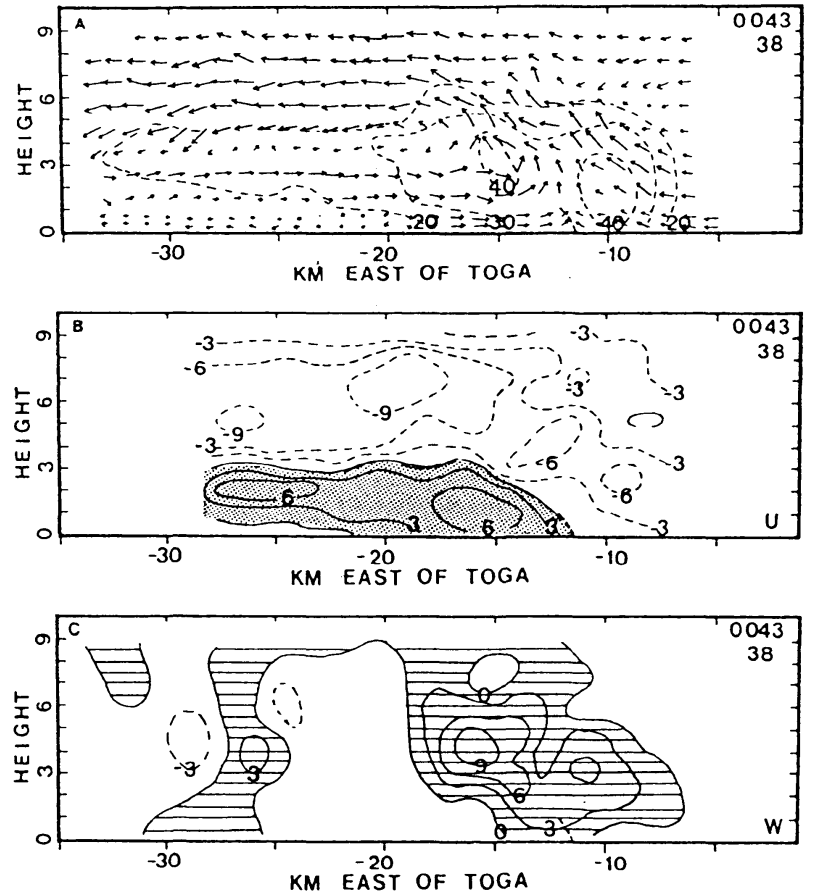

Fig. 11. The east-west vertical cross section at the northern portion of a north-south oriented squall line at 0043 LST 17 May 1987, showing (a) storm-relative wind with reflectivity contours superimposed, (b) the cross-line component $(\mathrm{u})$, and $(\mathrm{c})$ vertical velocity $(\mathrm{w})$. Contour intervals for $Z, u$, and $w$ are $10 \mathrm{dBZ}, 3$ and $3 \mathrm{~ms}^{-1}$, respectively. Negative values are dashed with positive values either shaded or hatched. The heavy dashed line signifies the gust front (From Wang et al., 1990).

cross section over northern part of this squall line. The convective updraft $\left(\geq 9 \mathrm{~ms}^{-1}\right)$ is tilted toward the west in the lower layer $(0-4 \mathrm{~km})$ heading toward the trailing stratiform region and rather strong and deep rear-to-front flow comes from the back of the leading edge. A density-current-type structure is evident at the leading edge as shown by a remarkable change in the $u$ component.

\section{Mesolow}

The lower tropospheric mesolows often formed over southeastern, southwestern, and northwestern Taiwan when the Mei-Yu front passed over Taiwan or its vicinity (Chen 1978b; 1990a). Figure 12 shows the frequency distribution of the mesolow formation in the Taiwan Mei-Yu season of 1972-1977. These mesolows were closely related to the rainfall over the Taiwan area (Chen, 1978b; 1990b; Chen and Chi, 1980b; Hsu, 1971). Climatological analysis by Chen (1978b) showed that the rainfall and mesolow over western Taiwan were positively correlated and the converse was true over eastern Taiwan. The mean

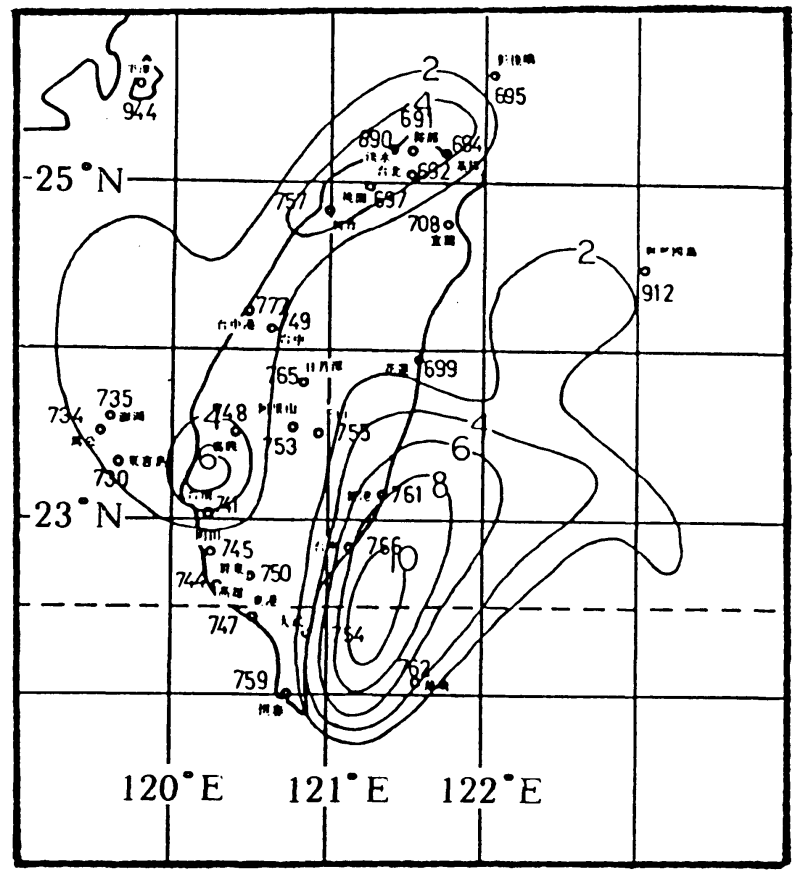

Fig. 12. The frequency distribution of the mesolow formation during 15 May-15 June 1972-1977 (From Chen, 1978b).

life span of mesolows was about $12-15 \mathrm{~h}$. They persisted longer in the later stage than in the earlier stage of the Mei-Yu season. Chen (1990a) observed that the mesolow had a longer life span on the east side than on the west side of the CMR. The mean intensity of mesolow was stronger over the ocean than over the land and stronger on the east side than on the west side. It was also found that the formation and the diurnal variation of mesolows were affected by the semi-diurnal pressure wave.

Chen and Chi (1980b) observed a close relationship between the heavy rainfall and mesolow over northwestern Taiwan. It was suggested that the mesolow over northwestern Taiwan probably served as a mechanism for producing heavy rainfall through enhanced southwesterlies. A case study by Chen (1979b) showed that mesolow formation and the accompanied wind changes over southwestern Taiwan were closely related to the enhancement of convective rainfall. This close relationship again existed in a recent study by Chen (1990b) using 18 cases of heavy rainfall events accompanying mesolows on the west side of the CMR in 1983-1987 Mei-Yu season. In that study the rainfall rate and radar echo intensified substantially when and after the mesolow formed. This intensification was perhaps due to the increase of local convergence which was caused by the increase of pressure gradient and low-level winds to the south of mesolow.

A case study by Chen (1979b) showed that a mesolow on the west coast of Taiwan had a horizontal scale of $200 \mathrm{~km}$ and was characterized by 

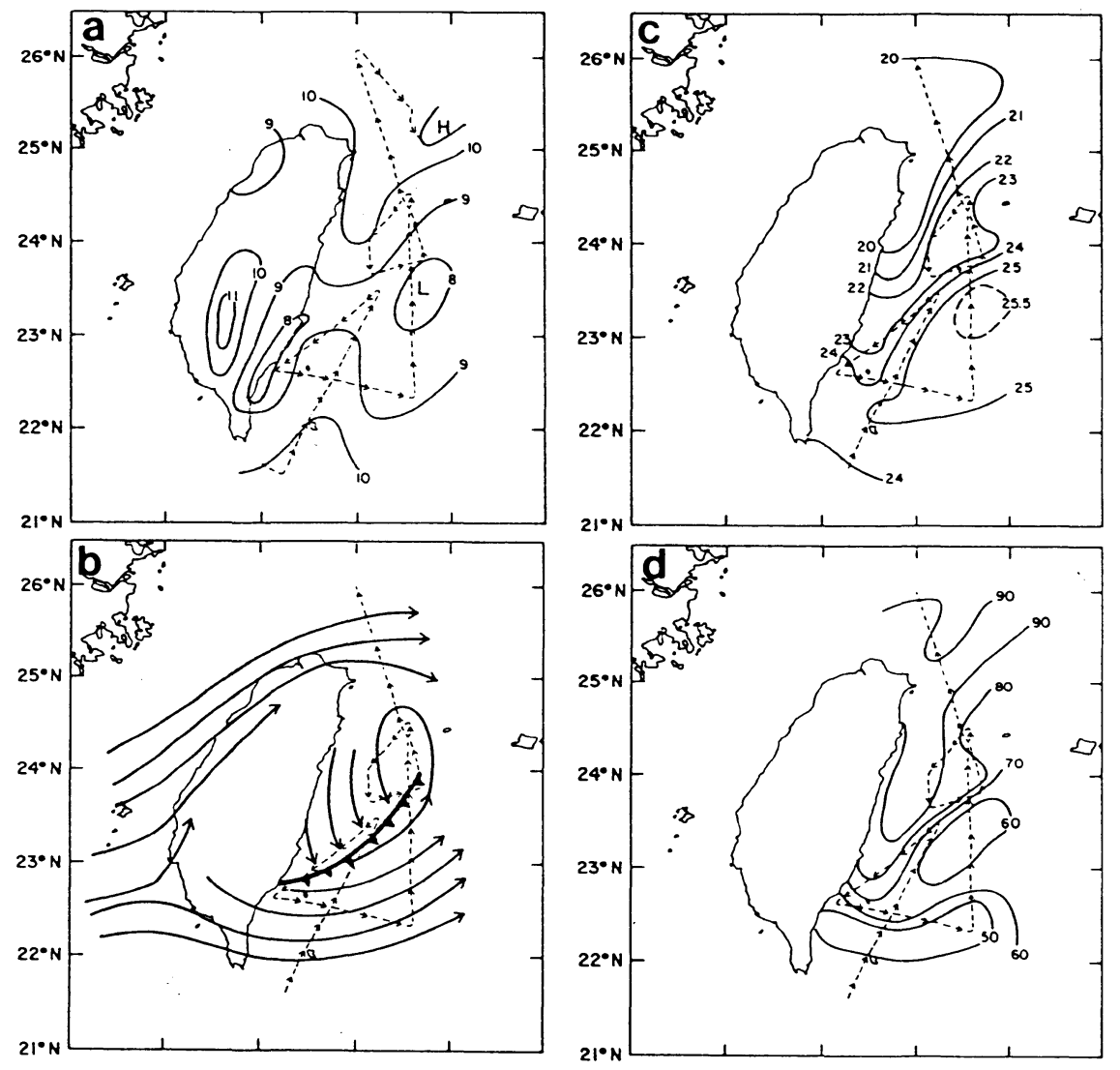

Fig. 13. Analysis at 1800 UTC 16 May 1987: (a) sea-level pressure (hPa), (b) 900-hPa streamline, (c) 900-hPa temperature $\left({ }^{\circ} \mathrm{C}\right)$, and (d) 900-hPa relative humidity (\%). Dashed arrows indicate P-3 flight tracks (From Kuo and Chen, 1990).

strong cyclonic vorticity, horizontal convergence and boundary layer upward motion. Chen and Yu (1990) found the mesolow over southwestern Taiwan was quite shallow (limited in the lowest $1.6 \mathrm{~km}$ ) with a horizontal scale of $150 \mathrm{~km}$ and was responsible for determining the intensity of heavy rainfall in southern Taiwan. In TAMEX field phase, a mesolow east of Taiwan was observed by P-3 aircraft on 16 May 1987. Figure 13 presents the structure as analyzed using in-situ observations from the aircraft coupled with the conventional data collected in the IOP (Kuo and Chen, 1990). The analysis shows two surface lows on the east side of the island. The southern low, which took an elongated shape, was located very close to the mountain over southeastern Taiwan where is the most favorable mesolow formation area as shown in Fig. 12. The other center (the primary mesolow) was located east of Hualien, to the northeast of the first low-pressure center. The central pressure of the lows was $1007 \mathrm{hPa}, \sim 2 \mathrm{hPa}-3$ $\mathrm{hPa}$ lower than the synoptic-scale pressure field. In addition to these two low-pressure centers, a mesohigh was observed on the windward side of the CMR (over southwestern Taiwan). The high/low pressure couplet across the CMR is consistent with the theoretical results of flow blocking by mesoscale moun- tains (Smith, 1982). Indeed, the wind field analysis (Fig. 13b) at the flight level ( $\sim 900 \mathrm{hPa})$ clearly reveals the low-level blocking and flow splitting upstream of the CMR. A strong horizontal wind shear existed to the east of Taiwan between the weak northerly flow and the strong southwesterly flow. On the eastern part of this shear line, a closed cyclonic circulation associated with the mesolow was observed. An analysis of the thermodynamic structure shows that the southwesterly flow was generally warmer and drier than the northerly flow (Figs. 13c and 13d). This cyclonic mesolow appeared to have a warm and dry core structure indicating the importance of subsidence in its formation.

In addition to the lower tropospheric mesolow, a mid-level cyclonic vortex was observed in TAMEX to the east of the CMR (Chen and Liang, 1990). It had a horizontal scale of about $100-200 \mathrm{~km}$ and a life span of more than $24 \mathrm{~h}$. Analyses showed that this vortex had a cold, moist core in the middle and lower troposphere (900-550 hPa; $1-5 \mathrm{~km}$ ) and tilted slightly northwestward towards the midtropospheric cold air in the early stage. It developed upward to the $300 \mathrm{hPa}(\sim 10 \mathrm{~km})$ warm region and downward to $950 \mathrm{hPa}(\sim 0.5 \mathrm{~km})$ in the later stage. It was proposed that the blocking effect coupled with 
the vertical vortex stretching process might be responsible for the formation of this vortex.

One of the very important issues related to the mesolow is the formation mechanism in different geographic areas to the southeast, southwest and northwest of Taiwan. For the mesolow over southeastern Taiwan, subsidence warming coupled with vertical vortex stretching process is one possible mechanism as suggested by observations which indicated a warm and dry lower troposphere and less rainfall in the mesolow area (Chen, 1978b; Kuo and Chen, 1990; Wang/S.T., 1989; Wang and Chen, 1990) and by the model simulations (Kuo et al., 1989; Lin, 1989; 1990; Mannouji and Kurihara, 1990). Low-level blocking coupled with flow separation is another mechanism suggested by observations (Wang/S.T., 1989; Wang and Chen, 1990) and by model studies (Huang and Raman, 1990; Sun and Wu, 1989). Numerical study by Soong et al. (1989), on the other hand, suggested that the diabatic heating and the associated sea breeze circulation can also be a mechanism for the formation of mesolow over southeastern Taiwan.

For the meoslow over northwestern Taiwan, a modelling study by Chern and Sun (1989) suggested that the formation is due to subsidence warming and lack of cold advection under the prevailing northeasterly flow to the north of Mei-Yu front. On the other hand, results of a non-linear semi-geostrophic model by Lin (1989) suggested that the formation of mesolow over northwest Taiwan under the prevailing southwesterly barotropic flow was due to diabatic cooling effect which increase the convergence in the mesolow area.

For the mesolow over southwestern Taiwan, observational studies suggested that both the convective latent heating (Chen, 1990b; Chen and Yu, 1990) and lack of cold air due to the flow blocking by the CMR (Chen and Hui, 1990; Chen and Liang, 1990; Chen et al., 1989) are possible formation mechanisms. Numerical study by Lin (1989) using a nonlinear semi-geostrophic model, on the other hand, suggested that a possible mechanism might be diabatic cooling effect which increases convergence over the mesolow area under the prevailing northwesterly baroclinic flow.

\section{Land-sea breeze}

From synoptic experience,the offshore flows in the night-time hours and onshore flows in the daytime, presumably the land-sea breeze, prevail in the Taiwan Mei-Yu season. Observations in the TAMEX cases showed that the sea breeze occurs in the lowest $1 \mathrm{~km}$ layer with a return flow in the 1-2 km layer (Chen et al., 1989; Lin and Sheng, 1990). The land breeze is usually much weaker and confined in the lowest $0.5 \mathrm{~km}$ layer (Lin and Sheng, 1990). This land-sea breeze circulation has been well simulated

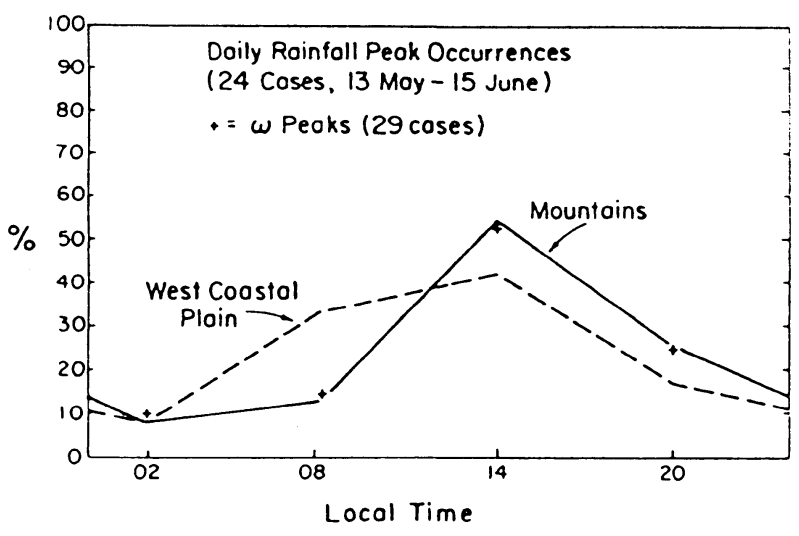

Fig. 14. Frequency distribution of daily rainfall peak occurrences based on 6-h totals for mountains and west coastal plain. Plusses indicate frequency distribution of $\omega$ peaks from Fig. 15 (From Bresch and Johnson, 1990).

in the numerical model with a complex terrain of the CMR (Huang and Raman, 1990; Soong et al., 1989).

Observational study of the case in 4-6 June 1986 by Chi and Chen (1989b) suggested that the local convergerce produced by the daytime sea breeze and the night-time land breeze are possible mechanisms for the formation and intensification of the MCSs. The diurnal variation of convective rainfall in the Mei-Yu season of 1975-1984 analyzed by Chen and Yang (1988b) showed a strong influence of the landsea breeze circulation. The strong forcing of land-sea breeze circulation on the local rainfall was also observed in the TAMEX cases (Bresch and Johnson, 1990; Johnson and Bresch, 1989; 1990). These observational results strongly suggest that the land-sea breezes are important local circulation to modulate rainfall in Taiwan Mei-Yu season under the weak synoptic conditions. It was found that most rainfall over the mountains occurred during the afternoon and evening hours and rainfall on the west coastal plains was shifted to slightly earlier times, consistent with the results of Chen and Yang (1988b) (see Fig. 10a). Figure 14 shows the frequency distribution of daily rainfall peak occurrences for mountains and west coastal plain during the Special Observing Period (SOP) (mid-May to mid-June) of TAMEX (Bresch and Johnson, 1990). There is a clear preference for the maximun rainfall amounts to occur in the afternoon and evening hours. This is in good agreement with the previous studies of Chen and Yang $(1988 \mathrm{a}, \mathrm{b})$.

A time series of vertical motion for the entire TAMEX SOP over Taiwan area was generated by Bresch and Johnson (1990) (Fig. 15). A regular diurnal pattern with upward motion during the afternoon and evening and downward motion at night is 


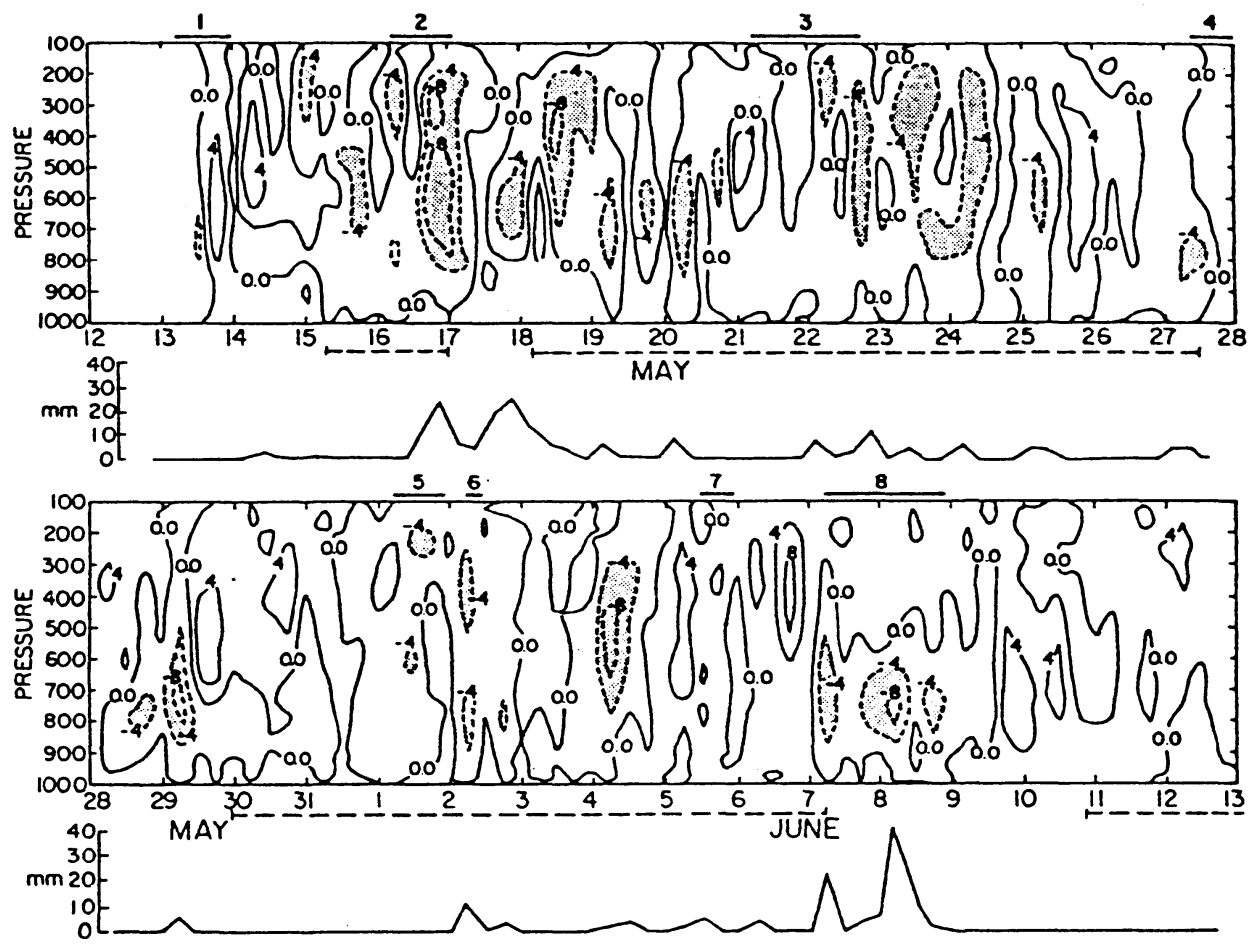

Fig. 15. Time series of ( $\mu$ bars or $0.1 \mathrm{~Pa} \mathrm{~s}^{-1}$ ) during the Special Observing Period. Strong upward motion areas are shaded. Intensive Observing Periods 1-8 are indicated at top. Horizontal dashed line denotes periods of conditional instability at Panchiao. Time series of average rainfall $(\mathrm{mm})$ over the sounding polygon for computing is shown at bottom of each panel (From Bresch and Johnson, 1990).

quite apparent. This pattern, as contributed by the land-sea breeze circulation, closely resembles the diurnal variation of rainfall (Fig. 14). It is apparent that during periods of conditional instability, the peaks in upward motion are generally in the mid- to upper troposphere indicating the presence of deep convection. Whereas during stable periods, upward motion peaks are in the lower troposphere suggesting the absence of deep convection.

\section{Island circulations}

The island circulations here are referred to the orographically induced mesoscale circulations which are due to the blocking and deflecting effects of the CMR on the prevailing flow under relatively undisturbed conditions. From synoptic experience, the deflecting effect of the prevailing westerly or southwesterly flow can produce local convergence in northwestern Taiwan and divergence in southwestern Taiwan. Figure 16 shows this feature in the TAMEX IOP-13 case (Chi and Chen, 1989a). In this case, the MCS intensified in northwestern Taiwan where the frontal forcing and the local convergence produced by the deflecting flow seemed to dominate. As the MCS moved over southwestern Taiwan, it weakened in the area of local divergence produced by deflecting flow. A case study of IOP-8 by Trier et al. (1990) showed that the splitting flow produced by the influence of the island barrier was felt at least
$150 \mathrm{~km}$ from the island. The deceleration of the lowlevel prefrontal westerlies resulting in a splitting of flow around the island produced higher surface pressure and divergent wind field in the vicinity of the southwest coast. The flow deflecting and splitting features under the prevailing southwesterlies have been well captured in the model simulations. The importance of the CMR in generating these features was clearly demonstrated in a modelling study by Mannouji and Kurihara (1990). Huang and Raman (1990) found that a strong southwesterly flow is generated locally in northwestern Taiwan due to the flow deflection. This is supported by an observational study (Shu, 1991) in that the southwesterly LLJ tended to intensify in northwestern Taiwan during TAMEX. Another interesting feature in the model simulation is that a line of convergence appears to form to the northeast of Taiwan due to the blocking and splitting effects of the CMR (Soong et al., 1989). However, the observational study of this feature is hampered by the lack of data over the ocean.

A splitting of the postfrontal flow at the northern tip of the island was observed in TAMEX IOP-8 case by Trier et al. (1990) and IOP-9 case by Chen and Hui (1990) who estimated the Froude number being 0.3. The Froude number is defined as $\mathrm{U} / \mathrm{NH}$, where $\mathrm{U}$ is the normal component of the upstream ambient flow, $\mathrm{H}$ is the obstacle height, and $\mathrm{N}$ is 


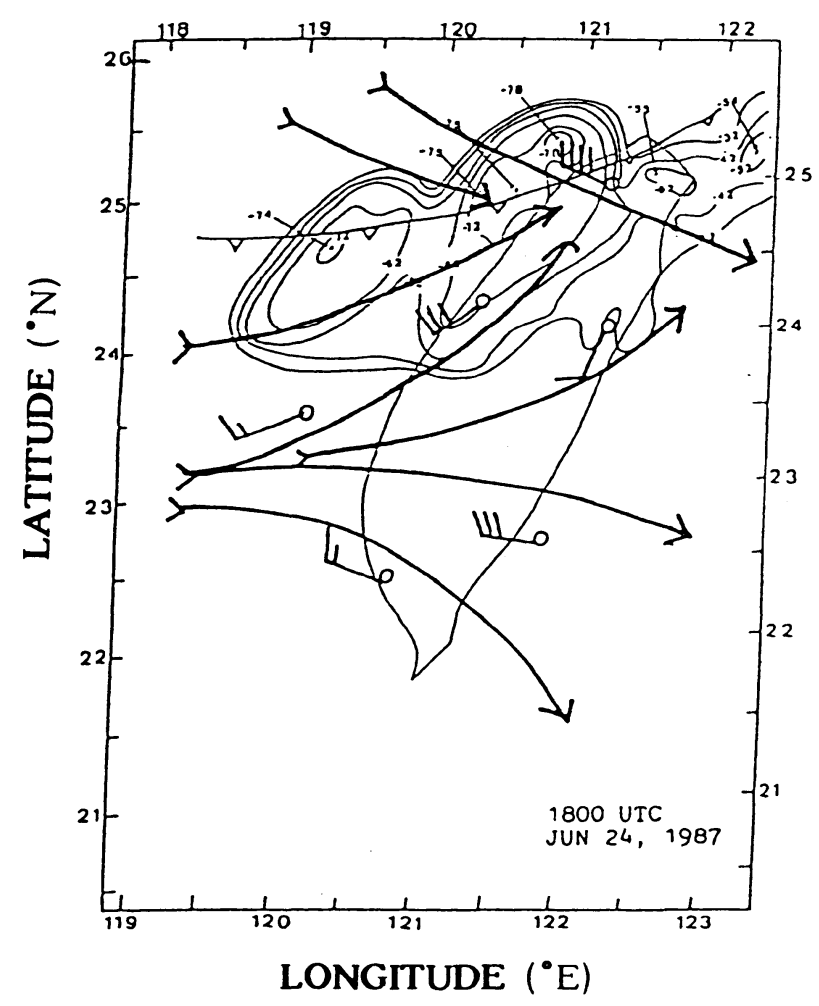

Fig. 16. Streamline analyses at $850 \mathrm{hPa}$ at 1800 UTC 24 June 1987. Thin solid lines and arrows indicate the cloud top temperatures and streamlines, respectively. Surface front is also indicated. Wind plots are conventional (From Chi and Chen, 1989a).

the Brunt-Vaisala frequency. This value is within the theoretical limit for flow blocking by obstacles. The cold air stacked over the windward slope leading to the pressure increase which was more significant on the northeast coast than on the northwest coast. The splitting ensures that the shallow, cold air mass never reaches the higher elevations of central Taiwan. In fact, a couplet of mesolow in southwestern Taiwan and a mesoscale ridge on the east side of the CMR (Chen and Liang, 1990; Chen et al., 1989) was primarily due to these blocking and splitting effects. Figure 17 shows the blocking effect over the southern Taiwan Strait off the south-western coast using P-3 aircraft in situ measurements (Chen and Hui, 1990). It is clear that the depth of cold air was about $450 \mathrm{~m}$ to the south of $23^{\circ} \mathrm{N}$ in the immediate vicinity of southwestern coast (Fig. 17b). However, this depth increased to about $1 \mathrm{~km}$ in the region where the northeasterlies were not obstructed by the island barrier. The shallowness of the cold air in the lee area was suggested by Chen and Hui to be due to the lateral spreading of the cold air as it moved around the island. As a result, the discontinuity in the wind fields at the $300-\mathrm{m}$ level was oriented southwest-northeast in the lee area (Fig. 17a). Another interesting feature in this case is that at the
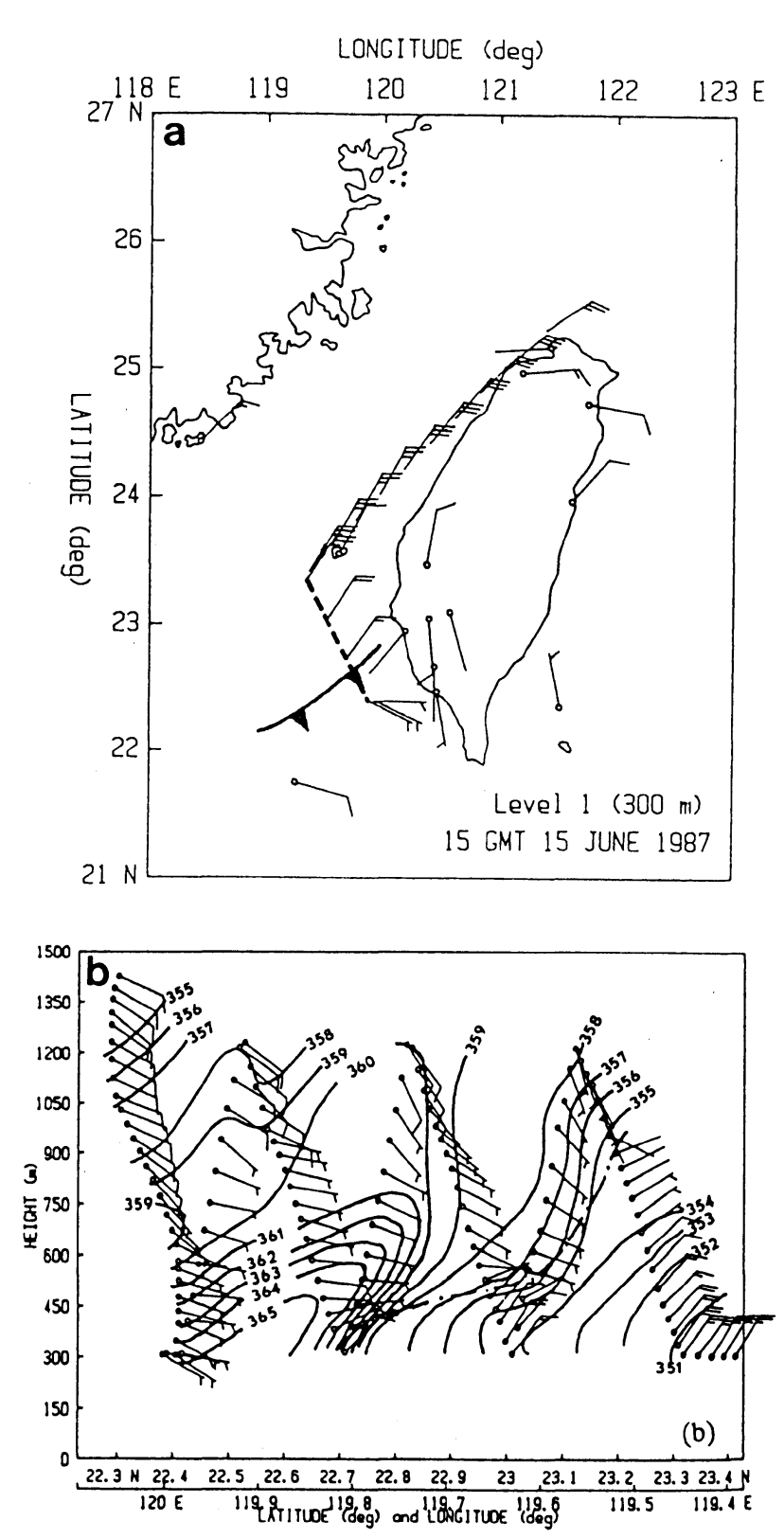

Fig. 17. (a) Horizontal wind fields constructed from rawinsonde data, pibal data, and aircraft observations between 15001800 UTC 15 June for $300 \mathrm{~m}$ above sea level. Dashed line indicates the vertical cross section shown in (b). (b) The southeast-northwest vertical cross section constructed from aircraft sawtooth pattern off the southwest coast of Taiwan. Horizontal winds in $\mathrm{ms}^{-1}$, with full barb and half barb representing $5 \mathrm{~ms}^{-1}$, and 2.5 $\mathrm{ms}^{-1}$, respectively. Equivalent potential temperature in K (solid) (From Chen and Hui, 1990). Dash-dotted line shows the sloping cold air boundary. 
leading edge, the warm, moist air was lifted by the cold, stable air. This is indicated by the presence of a warm, moist tongue above the sloping cold air boundary (Fig. 17b).

\section{Concluding remarks}

Mei-Yu (or Baiu) is a unique regional weather and climate phenomenon occurring in the period of late spring and early summer over East Asia and the western North Pacific. The heavy rainfall and the associated flash flooding occurred in the Mei-Yu season often caused tremendous property damage and loss of life. Therefore, one of the key issues in meteorological community is to improve, through better understanding, the forecasting of heavy rainfall events that lead to flash floods. The major objective of the Taiwan Area Mesoscale Experiment (TAMEX) is to study various scientific problems relevant to the heavy rainfall events.

The current understanding of the structure and dynamics of the mesoscale features observed in the Taiwan Mei-Yu season is presented in this paper. These features include the Mei-Yu front, low-level jet (LLJ), mesoscale convective systems (MCSs), mesolow, land-sea breeze, and island circulations. Research results in the pre-TAMEX era (before 1987) as well as those derived from TAMEX field program are reviewed and discussed. Admittedly, this review is not meant to be comprehensive and final. More scientific results of the on-going TAMEX research from various groups can be expected in the forth comming years. From this paper, it is quite clear that more research efforts are needed in the theoretical, modelling, and observational aspects of these interesting mesoscale features which are relevant to heavy rainfall not only in Taiwan area but also in other parts of the world.

\section{Acknowledgements}

The author wishes to express his appreciation to Mr. T.A. Wang, J.S. Yang, and C.C. Wang in preparing this manuscript. Thank Dr. M. Yoshizaki and anonymous referee for valuable comments and suggestions. This work is supported by the National Science Council under Grant NSC 80-0202-M002-19.

\section{References}

Akiyama, T., 1973: Ageostrophic low level jet stream in the Baiu season associated with heavy rainfalls over the sea area. J. Meteor. Soc. Japan, 51, 205-208.

Blackadar, A.K., 1957: Boundary layer wind maxima and their significance for the growth of nocturnal inversions. Bull. Amer. Meteor. Soc., 38, 283-290.

Bell, G.D. and L.F. Bosart, 1988: Appalachian cold-air damming. Mon. Wea. Rev., 116, 137-161.

Bresch, J.F. and R.H. Johnson, 1990: Rainfall and vertical motion associated with TAMEX precipitation systems. Proc. Workshop on TAMEX Scientific
Results, NCAR, 24-26 September, 84-89. [Available from Mesoscale and Microscale Meteor. Div., NCAR, P.O. Box 3000, Boulder, CO 80307]

Chen, C.K., 1979: An analysis of the relationship between the low level jet stream and the heavy rainfall during the Mei-Yu season in Taiwan. Atmos. Sci., 6, 1, 29-37. (in Chinese with English abstract).

Chen, C.S., 1989: The relationship between low-level lifting and the formation of new convection in MeiYu season. Papers Meteor. Res., 12, 1-16.

Chen, C.S., 1990: A numerical study of the terrain effects on a squall line. Terrestrial Atmos. Oceanic Sci., 1, 73-90.

Chen, C.S., T.K. Chiou and S.T. Wang, 1986: An investigation of mesoscale convective systems associated with Mei-Yu front in SE China from May 26 to 28, 1985. Papers Meteor. Res., 9, 2, 137-161.

Chen, G.T.J.,1977a: An analysis of moisture structure and rainfall for a Mei-Yu regime in Taiwan. Proc. Natl. Sci. Counc., 1, 11, 1-21.

Chen, G.T.J., 1977b: A synoptic case study on mean structure of Mei-Yu in Taiwan. Atmos. Sci., 4, 3847.

Chen, G.T.J., 1978a: The structure of a subtropical MeiYu system in Southeast Asia. Sci. Rep., Dept. of Atmos. Sci. Natl. Taiwan Univ., 2, 9-23. [Available from the Dept. of Atmos. Sci., Natl. Taiwan Univ., Taipei, Taiwan, R.O.C.]

Chen, G.T.J., 1978b: On the meso-scale systems for the Mei-Yu regime in Taiwan. Proc. Conf. Severe Weather in Taiwan Area, NSC and Academia Sinica, 150-157 (in Chinese with English abstract). [Available from the Dept. of Atmos. Sci., Natl. Taiwan Univ., Taipei, Taiwan: R.O.C.]

Chen, G.T.J., 1979a: On the moisture budget of a MeiYu system in southeastern Asia. Proc. Natl. Sci. Counc., 3, 1, 24-32.

Chen, G.T.J., 1979b: Mesoscale analysis for a Mei-Yu case over Taiwan. Papers Meteor. Res., 2, 63-74.

Chen, G.T.J., 1983: Observational aspects of the MeiYu phenomena in subtropical China. J. Meteor. Soc. Japan, 61, 306-312.

Chen, G.T.J., 1985: Feasibility study of "A Severe Regional Precipitation Observation and Analysis Experiment". Natl. Sci. Counc., Sci. and Tech. of Disaster Prevention Program, Tech. Rep. 73-42, 32 pp (in Chinese with English abstract). [Available from the Dept. of Atmos. Sci., Natl. Taiwan Univ., Taipei, Taiwan, R.O.C.]

Chen, G.T.J., 1988: On the synoptic-climatological characteristics of the east Asian Mei-Yu front. Atmos. Sci., 16, 435-446 (in Chinese with English abstract).

Chen, G.T.J., 1990a: On the climatological characteristics of the mesolow in Taiwan Mei-Yu season. Atmos. Sci., 18, 73-84 (in Chinese with English abstract).

Chen, G.T.J., 1990b: Study of rainfalls and radar echoes in the heavy rainfall events accmpanied by mesolow in Mei-Yu season. Atmos. Sci., 18, 213-228 (in Chinese with English abstract).

Chen, G.T.J., 1990c: Overview of Mei-Yu research in Taiwan. East Asia and Western Pacific Meteorology 
and Climate. P. Sham and C.P. Chang, Eds., World Scientific Publishing Co., 14-37.

Chen, G.T.J. and C.P. Chang, 1980: The structure and vorticity budget of an early summer monsoon trough (Mei-Yu) over southeastern China and Japan. Mon. Wea. Rev., 108, 942-953.

Chen, G.T.J. and S.S. Chi, 1978: On the meso-scale structure of Mei-Yu front in Taiwan. Atmos. Sci., 5, 1, 35-47 (in Chinese with English abstract).

Chen, G.T.J. and S.S. Chi, 1980a: On the frequency and speed of Mei-Yu front over southern China and the adjacent areas. Papers Meteor. Res., 3, 1\&2, 31-42.

Chen, G.T.J. and S.S. Chi, 1980b: On the mesoscale rainfall and meso-low in the Mei-Yu season in Taiwan. Atmos. Sci., 7, 39-48 (in Chinese with English abstract).

Chen, G.T.J. and H.C. Chou, 1989: Squall lines observed during TAMEX. Proc. Workshop on TAMEX Preliminary Scientific Results, Taipei, 22-30 June, 35-42. [Available from the Dept. of Atmos. Sci., Natl. Taiwan Univ., Taipei, Taiwan, R.O.C.]

Chen, G.T.J. and C.Y. Liang, 1990: Observational study of a midlevel vortex in TAMEX. Proc. Workshop on TAMEX Scientific Results, NCAR, 24-26 September, 13-25. [Available from Mesoscale and $\mathrm{Mi}$ croscale Meteor. Div., NCAR, P.O. Box 3000, Boulder, CO 80307]

Chen, G.T.J. and C.P. Pu, 1985: A case study of the formation of a low level jet over subtropical China and heavy precipitation in northern Taiwan. Atmos. Sci., 12, 23-32 (in Chinese with English abstract).

Chen, G.T.J. and C.Y. Tsay, 1978: $\Lambda$ synoptic case study of Mei-Yu near Taiwan. Papers Meteor. Res., 1,2536 .

Chen, G.T.J. and C.C. Wu, 1978: On the climatological charactericties at five cities in Taiwan. Atmoc. Sci., 5, 2, 1-16 (in Chinese with English abstract).

Chen, G.T.J., C.W. Wu and S.S. Chi, 1986: Climatological aspects of the mesoscale convective systems over subtropical China and the western North Pacific during Mei-Yu season of 1981-1983. Atmos. Sci., 13, 33-45 (in Chinese with English abstract).

Chen, G.T.J. and T.Y. Wu, 1985: Pilot study of "A Severe Regional Precipitaion Observation and Analysis Experiment". Natl. Sci. Counc., Sci. and Tech. of Disaster Prevention Program, 108 pp (in Chinese with English abstract). [Available from the Dept. of Atmos. Sci., Natil, Taiwan Univ., Taipei, Taiwan, R.O.C.]

Chen, G.T.J. and J.S. Yang, 1988a: On the spatial and temporal patterns of heavy rainfall in Taiwan Mei-Yu season. Atmos. Sci., 16, 151-162 (in Chinese with English abstract).

Chen, G.T.J. and J.S. Yang, 1988b: Climatological aspects of convective rainfall over Taiwan area in MeiYu season. Proc. Conference on Weather Analysis and Forecasting, Central Weather Bureau, Taipei, 565-571. [Available from the Central Weather Bureau, 64 Kung Yuan Rd., Taipei, Taiwan, R.O.C.]

Chen, G.T.J. and C.C. Yu, 1988: Study of low-level jet and extremely heavy rainfall over northern Taiwan in the Mei-Yu season. Mon. Wea. Rev., 116, 884-891.
Chen, G.T.J. and C.C. Yu, 1990: Role of Mei-Yu front and mesolow on the heavy rainfall events: Two cases in TAMEX phase I (1986). Atmos. Sci., 18, 129-147 (in Chinese with English abstract).

Chen, L.F., 1986: A synoptic scale diagnostic study of a heavy rain event in northern Taiwan of 1984. Meteor. Bull., 32, 4, 29-60 (in Chinese with English abstract).

Chen, Q., 1982: The instability of the gravity-inertia wave and its relation to low-level jet and heavy rainfall. J. Meteor. Soc. Japan., 60, 1041-1057.

Chen, Y.L. and N.B.F. Hui, 1990: Analysis of a shallow front during Taiwan Area Mesoscale Experiment. Mon. Wea. Rev., 118, 2649-2667.

Chen, Y.L., Y.X. Zhang and N.B.F. Hui, 1989: Analysis of a surface front during the early summer rainy season in Taiwan. Mon. Wea. Rev., 117, 909-931.

Chern, J.D. and W.Y. Sun, 1989: Lee cyclogenesis and interaction between front and mountain. Proc. Workshop on TAMEX Preliminary Scientific Results, Taipei, 22-30 June, 343-346. [Available from the Dept. of Atmos. Sci., Natl. Taiwan Univ. Taipei, Taiwan, R.O.C.]

Chi, S.S. and G.T.J. Chen, 1988: A diagnostic case study of the environmental conditions associated with mesoscale convective complexes: 27-28 May 1981 Case. Atmos. Sci., 16, 14-30 (in Chinese with English abstract)

Chi, S.S. and Cr.T.J. Chen, 1989a: A study on the MICS case of TAMEX IOP-13. Proc. Workshop on TAMEX Preliminary Scientific Results, Taipei, 2230 June, 14-21. [Available from the Dept. of Atmos, Sci., Natl. Taiwan Univ., Taipei, Taiwan, R.O.C.]

Chi, S.S. and G.T.J. Chen, 1989b: Case study of the MCSs and rainfall during TAMEX/Phase I. Atmo. Sci., 17, 59-75 (in Chinese with English abstract).

Chi, S.S. and G.T.J. Chen, 1989c: A moisture budget analysis of two MCC cases during Taiwan Mei-Yu season. Papers Meteor. Res., 12, 143-157.

Chiou, T.K. and C.S. Chen, 1989: The structure of mesoscale convective systems in Southern China during the Mei-Yu period. Papers Meteor. Res., 11, 195-217.

Chiou, T.K. and S.Y. Liao, 1984: A study of mesoscale convective system in the southern China and its vicinity. Atmos. Sci., 11, 85-100 (in Chinese with English abstract).

Chiou, T.K. and F.C. Liu, 1985: A case study of heavy rainfall in northern Taiwan on June 3, 1984. Atmos. Sci., 12, 93-102 (in Chinese with English abstract).

Chou, L.C., C.P. Chang and R.T. Williams, 1990: A numerical simulation of the Mei-Yu front and the associated low-level jet. Mon. Wea. Rev., 118, 14081428.

Chu, C.M. and C.S. Chen, 1988: The analysis of environmental conditions associated with mesoscale convective systems in SE China. Atmos. Sci., 16, 349-371 (in Chinese with English abstract).

Chu, K.K., K.Y. Liu, I.F. Chang and W.C. Yeh, 1983: The causes of special distribution of heavy rainfall in Taiwan. Quart. J. Meteor., 97, 1-15 (in Chinese with English abstract). 
Forbes, G.S., R.A. Anthes and D.W. Thomson, 1987: Synoptic and mesoscale aspects of an Appalachian ice storm associated with cold-air damming. Mon. Wea. Rev., 115, 564-591.

Hsu, C.H., 1971: A study of heavy rain in the Taipei area. Meteor. Bull., 17, 3, 49-71 (in Chinese with English abstract).

Hsu, M.T. and S.S. Chi, 1974: On the analysis of Mei-Yu in Taiwan. Meteor. Bull., 20, 4, 25-44 (in Chinese with English abstract).

Huang, C.Y. and S. Raman, 1990: Numerical simulations of Taiwan island circulations: diurnal modification. Proc. Workshop on TAMEX Scientific Results, NCAR, 24-26 September, 199-203. [Available from Mesoscale and Microscale Meteor. Div., NCAR, P.O. Box 3000, Boulder, CO 80307]

Johnson, R.H. and J.F. Bresch, 1989: Interaction between sea and land breezes and deep convction over Taiwan. Proc. Workshop on TAMEX Preliminary Scientific Results, Taipei, 22-30 June, 1-5. [Available from the Dept. of Atmos. Sci., Natl. Taiwan Univ., Taipei, Taiwan, R.O.C.]

Johnson, R.H. and J.F. Bresch, 1990: Heating and moistening distributions within TAMEX precipitation systems. Proc. Workshop on TAMEX Scientific Results, NCAR, 24-26 September, 90-94. [Availabel from Mesoscale and Microscale Meteor. Div., NCAR, P.O. Box 3000, Boulder, CO 80307]

Jorgensen, D.P. and M.A. LeMone, 1989: Vertical velocity characteristics of oceanic convection. J. Atmos. Sci., 46, 621-640.

Jou, B.J.D., J.S. Hong and S.M. Deng, 1990: DualDoppler radar analysis of a convective (Mei-Yu) frontal rainband. Atmos. Sci., 18, 239-264 (in Chinese with English abstract).

Kuo, Y.H. and R.A. Anthes, 1982: Numerical simulation of a Mei-Yu system over southeastern Asia. Papers Meteor. Res., 5, 15-36.

Kuo, Y.H., J.W. Bao and S. Chen, 1989: Structure and dynamics of the meso-low observed during TAMEX IOP-2. Part II: mesoscale numerical simulations. Proc. Workshop on TAMEX Preliminary Scientific Results, Taipei, 22-30 June, 339-342. [Available from the Dept. of Atmos. Sci., Natl. Taiwan Univ., Taipei, Taiwan, R.O.C.]

Kuo, Y.H. and G.T.J. Chen, 1990: Taiwan Area Mesoscale Experiment: An Overview. Bull. Amer. Meteor. Soc., 71, 488-503.

Lee, C.S., 1990: The moisture and energy budgets over Taiwan strait during TAMEX. Atmos. Sci., 18, 111127 (in Chinese with English abstract).

Lettau, H.H., 1967: Small to large scale features of boundary structures over mountain slopes. Proc. Symposium on Meterology, Colorado State University, 1-74. [Availabel from Dept. Atmos. Sci., Colorado State Univ., Fort Collins, CO 80523]

Lin, M.S. and S.M. Lin, 1989: A case study of the mesoscale convetive system during TAMEX phase I. Atmos. Sci., 17, 257-270 (in Chinese with English abstract).

Lin, P.L. and Y.V. Sheng, 1990: A preliminary study on the characteristics of sea and land breezes in Taiwan area during TAMEX period. Proc. Conference on
Weather Analysis and Forecasting. Central Weather Bureau, Taipei, 133-144 (in Chinese with English abstract). [Availabel from the Central Weather Bureau, 64 Kung Yuan Rd., Taipei, Taiwan, R.O.C.]

Lin, P.L., T.C.C. Wang and C.C. Yeh, 1989: Doppler observational study of a long-lived rainband in TAMEX IOP-13. Papers Meteor. Res., 12, 91-119.

Lin, S.C., 1988: The life cycle and structure of a mesoscale convective system occurring in the Southern China area during Mei-Yu season. Papers Meteor. Res., 11, 1-26.

Lin, S.C. and T.K. Chiou, 1985: Objective scale separation technique and its application on the mesoscale convective system diagnosis. Papers Meteor. Res., 8, 2, 69-94.

Lin, S.C. and C.M. Tsai, 1989: Kinetic energy budgets of a mesoscale convective system occurring in the MeiYu season. Atmos. Sci., 17, 187-209 (in Chinese with English abstract).

Lin, S.M. and M.S. Lin, 1988: A case study of mesoscale convective systems during the TAMEX phase I. Atmos. Sci., 16, 163-174 (in Chinese with English abstract)

Lin, Y.J., T.C.C. Wang, R.W. Pasken, H. Shen and Z.S. Deng, 1990: Characteristics of a subtropical squall line determined from TAMEX dual-Doppler data. Part 2: Dynamic and thermodynamic structure and momentum budgets. J. Atmos. Sci., 47, 2382-2399.

Lin, Y.L., 1989: A study of flow over a mesoscale mountain with diabatic heating. Proc. Workshop on TAMEX Preliminary Scientific Results, Taipei, 22-30 June, 327-333. [Available from the Dept. of Atmos. Sci., Natl. Taiwan Univ., Taipei, Taiwan, R.O.C.]

Lin, Y.L., 1990: Formation mechanisms of Taiwan mesolows during the Mei-Yu season. Proc. Workshop on TAMEX Scientific Results, NCAR, 24-26 September, 174-181. [Availabel from Mesoscale and Microscale Meteor. Div., NCAR, P.O. Box 3000, Boulder, CO 80307]

Liu, K.Y., 1981: A study of the heavy rainfall in the Mei-Yu seasons of Taiwan. Quart. J. Meteor., 88, 7-12 (in Chinese with English abstract).

Liu, K.Y., 1982: On the heavy rainfall of May 28, 1981. Quart. J. Meteor., 91, 1-10 (in Chinese with English abstract).

Maddox, R.A., 1980: Mesoscale convective complexes. Bull. Amer. Meteor. Soc., 61, 1374-1387.

Maddox, R.A., 1983: Large-scale meteorological conditions associated with midlatitude, mesoscale convective complexes. Mon. Wea. Rev., 111, 1475-1493.

Mannouji, N. and K. Kurihara, 1990: A numerical experiment of TAMEX IOP\#13 by the spectral limited area model of the JMA. Proc. Workshop on TAMEX Scientific Results, NCAR, 24-26 September, 121-126. [Available from Mesoscale and Microscale Meteor. Div., NCAR, P.O. Box 3000, Boulder, CO 80307]

Matsumoto, S., 1972: Unbalanced low-level jet and solenoidal circulation associated with heavy rainfalls. J. Meteor. Soc. Japan, 50, 194-203.

Matsumoto, S. and K. Ninomiya, 1969: On the role of convective momentum exchange in the mesoscale 
gravity wave. J. Meteor. Soc. Japan, 47, 75-85.

Matsumoto, S., K. Ninomiya and S. Yoshizumi, 1971: Characteristic features of "Baiu" front associated with heavy rainfall. J. Meteor. Soc. Japan, 49, 267281.

Newton, C.W., 1956: Mechanisms of circulation change during a lee cyclogenesis. J. Meteor., 13, 528-539.

Ninomiya, K., 1980: Enhancement of Asia subtropical front due to thermodynamic effect of cumulus convections. J. Meteor. Soc. Japan, 58, 1-15.

Ninomiya, K. and T. Akiyama, 1974: Band structure of mesoscale echo cluster associated with low-level jet stream. J. Meteor. Soc. Japan, 52, 300-313.

Ninomiya, K. and Y. Tatsumi, 1980: Front with heavy rainfalls in the Asian subtropical humid region in a 6 -level $77 \mathrm{~km}$ mesh primitive equation model. $\mathrm{J} . \mathrm{Me}$ teor. Soc. Japan, 58, 172-185.

Parsons, D.B., S.B. Trier and J.B. Klemp, 1989: Numerical simulations of frontal updrafts observed in subtropical and middle latitudes. Proc. Workshop on TAMEX Preliminary Scientific Results, Taipei, 2230 June, 6-13. [Available from the Dept. of Atmos. Sci., Natl. Taiwan Univ., Taipei, Taiwan, R.O.C.]

$\mathrm{Pu}$, C.P. and G.T.J. Chen, 1988: A preliminary analysis of the low-level jet and mesoscale convective systems over subtropical China during Mei-Yu season: The case of June 1-3, 1983. Meteor. Bull., 34, 285-297 (in Chinese with English abstract).

Rotunno, R., J.B. Klemp and M.J. Weisman, 1988: A theory for strong, long-lived squall lines. J. Atmos. Sci., 45, 463-485.

Smith, R.B., 1982: Synoptic observation and theory of orographically disturbed wind and pressure. $J$. Atmos. Sci., 39, 60-70.

Soong, S.T., M. Mathur and W.K. Tao, 1989: The effect of topography and diurnal heating cycle on airflow and precipitation in Taiwan. Proc. Workshop on TAMEX Preliminary Scientific Results, Taipei, 22-30 June, 304-309. [Available from the Dept. of Atmos. Sci., Natl. Taiwan Univ., Taipei, Taiwan, R.O.C.]

Shu, I.S., 1991: A study of low-level jet in Taiwan area during TAMEX. M.S. Thesis, Dept. Atmos. Sci., Natl. Taiwan Univ., $89 \mathrm{pp}$ (in Chinese). [Available from the Dept. of Atmos. Sci., Natl. Taiwan Univ., Taipei, Taiwan, R.O.C.]

Sun, W.Y. and C.C. Wu, 1989: Numerical simulation of mesoscale circulation in Taiwan and surrounding area. Proc. Workshop on TAMEX Preliminary Scientific Results, Taipei, 22-30 June, 173-176. [Available from the Dept. of Atmos. Sci., Natl. Taiwan Univ., Taipei, Taiwan, R.O.C.]

TAMEX Workshop, 1989: Proc. Workshop on TAMEX Preliminary Scientific Results. Taipei, 22-30 June, 373 pp. [Available from the Dept. of Atmos. Sci., Natl. Taiwan Univ., Taipei, Taiwan, R.O.C.]

TAMEX Workshop, 1990: Proc. Workshop on TAMEX Scientific Results. NCAR, 24-26 September, 208 pp. [Available from Mesoscale and Microscale Meteor. Div., NCAR, P.O. Box 3000, Boulder, CO 80307]

Tao, S.Y. and L.X. Chen, 1987: A review of recent research on the East Asian summer monsoon in China.
Monsoon Meteorology, C.P. Chang and T.N. Krishnamurti, Eds., Oxford University Press, 60-92.

Trier, S.B., D.B. Parsons and T.J. Matejka, 1990: Observations of a subtropical cold front in a region of complex terrain. Mon. Wea. Rev., 118, 2449-2470.

Tsay, C.Y. and B.F. Chain, 1987: A composite study of low level jet and it's relationship with heavy rainfall in Taiwan area during Mei-Yu season. Atmos. Sci., 15, 1, 1-16 (in Chinese with English abstract).

Tsay, C.Y. and G.T.J. Chen, 1980: Dynamic processes for vertical motion in a Mei-Yu system. Papers. Meteor. Res., 3, 67-77.

Tsay, C.Y. and W.S. Kau, 1989: The coupling of upperlevel and low-level jet streaks during Taiwan heavy rainfall period in Mei-Yu season. Papers Meteor. Res., 12, 17-32.

Uccellini, L.W. and D.R. Johnson, 1979: The coupling of upper and lower tropospheric jet streaks and implication for the development of severe convective storms. Mon. Wea. Rev., 107, 682-703.

Wang, S.T., 1970: On the Plum Rain in Taiwan. Quart. J. Meteor., 44, 12-20 (in Chinese with English abstract).

Wang, S.T., 1986: Observational analysis of the interaction between fronts and orography in Taiwan during the late winter monsoon season. Preprints, International Conference on Monsoon and Mesoscale Meteorology, November 4-7, Taipei, 123-135. [Available from the Meteor. Soc. of the R.O.C., 64 Kung Yuan Rd., Taipei, Taiwan, R.O.C.]

Wang, S.T., 1989: Observational study of the orographically induced disturbances during TAMEX. Proc. Workshop on TAMEX Preliminary Scientific Results, Taipei, 22-30 June, 279-286. [Availabel from the Dept. of Atmos. Sci., Natl. Taiwan Univ., Taipei, Taiwan, R.O.C.]

Wang, S.T. and G.T.J. Chen, 1990: On the formation and structure of mesolows in TAMEX. Proc. Workshop on TAMEX Scientific Results, NCAR, 24-26 September, 166-173. [Available from Mesoscale and Microscale Meteor. Div., NCAR, P.O. Box 3000, Boulder, CO 80307]

Wang, T.C.C., 1988: The radar analysis of two precipitation systems during $1986 \mathrm{Mei}-Y u$ season. Papers Meteor. Res., 11, 63-94.

Wang, T.C.C., 1989: The formation of new convection at the intersection of two line echo systems during TAMEX IOP\#2. Papers Meteor. Res., 12, 75-90.

Wang, T.C.C., Y.J. Lin, R.W. Pasken and H. Shen, 1990: Characteristics of a subtropical squall line determined from TAMEX dual-Doppler data. Part I: Kinematic structure. J. Atmos. Sci., 47, 2357-2381.

Wexler, H., 1961: A boundary layer interpretation of the low-level jet. Tellus, 13, 369-378.

Wu, C.W. and G.T.J. Chen, 1988: Composite structure of environmental conditions associated with MCCs in Taiwan Mei-Yu season. Proc. Conference on Weather Analysis and Forecasting, Central Weather Bureau, Taipei, 95-106 (in Chinese with English abstract). [Available from the Central Weather $\mathrm{Bu}$ reau, 64 Kung Yuan Rd., Taipei, Taiwan, R.O.C.] 


\section{台湾の梅雨（Mei-Yu）期に観測されるメソスケール降水系の特徵 \\ George Tai-Jen Chen \\ (国立台湾大学理学院大気科学系)}

組織化されたメソスケール対流系 (MCSs) で構成される雲帯は、東アジアの梅雨前線を特徴づけるも のであるが、本研究では、この中で台湾における梅雨（Mei-Yu）期に観測されるメソスケール降水系の 構造とダイナミックスについてレヴューする。本レヴューでは、メソスケール降水系の特別観測の行なわ れたTAMEX の成果も含めて議論する。

大規模場の特徴として下層ジェット（LLJ）は梅雨前線の南側にしばしば観測され、MCSs や豪雨の発生と 密接な関係がある。大規模の梅雨前線が台湾に近づくと、前線のメソスケールでのふるまいや MSCs は台湾の 地形（中央山脈）に影響を受ける。すなわち、島の地形と、周囲の海とのコントラスト、により形成される海 陸風やその他の局地循環、及びメソ低気圧は、降水系のメソスケールでのふるまいにとり、重要な因子である。 